\title{
NOWA INTERPRETACJA DOGMATU IN SENSU RECTO: ZAGADNIENIE NIEŚMIERTELNOŚCI W STANIE SPRAWIEDLIWOŚCI PIERWOTNEJ
}

\section{DOGMAT I JEGO TRADYCYJNA INTERPRETACJA TEOLOGICZNA}

Do podstawowych treści dogmatycznych katolicyzmu należy następujące twierdzenie: przed upadkiem pierworodnym, który pociągnął za sobą grzech pierworodny, człowiek żył w stanie sprawiedliwości pierwotnej, tzn. posiadał dary łaski uświęcającej. Do tej właśnie treści sprowadza się dogmat istnienia stanu sprawiedliwości pierwotnej po odrzuceniu wszystkiego, co nie zostało dogmatycznie zdefiniowane. Chociaz podstawowa dla katolicyzmu, to jednak sama w sobie jest uboga, dopóki na nią patrzymy w oderwaniu od reszty dogmatów i od całości nauki objawionej. Kiedy zaś zaczynamy ją rozważać w świetle całości twierdzeń dogmatycznie zdefiniowanych oraz całości nauki objawionej, zaczyna się rozumienie czyli interpretacja dogmatu pojętego jako treść, tj. in sensu recto.

Ponadnaukową interpretację tego dogmatu dał $\mathrm{m}$. in. kanon drugi trydenckiej definicji dogmatycznej o grzechu pierworodnym, gdy orzekł, że jest on śmiercią duszy (DS 1512): śmierci nie można przecież pojąć nie założywszy uprzedniego życia i dlatego grzech pierworodny okazuje się przeciwieństwem stanu sprawiedliwości pierwotnej. Zadaniem naukowej, teologicznej interpretacji jest zaś odpowiedzieć metodycznie na pytanie: jakie cechy przypisuje objawienie stanowi sprawiedliwości pierwotnej? Ponieważ od rodzaju tych cech zależało, jaką rolę miał pełnić w życiu człowieka przed upadkiem stan sprawiedliwości, dlatego ich naukowe ustalenie jest prawdziwie teologiczną interpretacją tegoj. stanu. 
Tradycyjna w dogmatyce katolickiej interpretacja teologiczna staru sprawiedliwości pierwotnej zakłada, że jego zasadniczą istotą było posiadanie darów łaski uświęcającej przed upadkiem, i wyraża się w następujących siedmiu twierdzeniach: 1) Człowiek przed upadkiem posiadał dary łaski uświęcającej od pierwszej chwili swego życia. To twierdzenie bywa oceniane jako opinio communis, tj. przyjmowane przez ogół teologów. 2) Człowiek przed upadkiem miał przez Boga przyobiecaną wolność od cielesnej śmierci: donum immortalitatis. Na mocy dekretu soboru trydenckiego o grzechu pierworodnym jest to dogmat wiary. 3) Człowiek przed upadkiem był wolny od chorób i cierpień: status felicitatis. Opinio communis. 4) Człowiek przed upadkiem był wolny od pożądliwości grzesznej, concupiscentia: donum innocentiae. To zaś twierdzenie bywa oceniane jako bliskie wiary, proxima fidei: wprawdzie samo w sobie nie zostało dogmatycznie zdefiniowane, ale jest tak ściśle związane $\mathrm{z}$ dogmatem, że posiada pewność wiary. 5) Człowiek przed upadkiem posiadał doskonałą wiedzę o Bogu i o świecie: donum scientiae. Opinio communis. 6) Człowiek przed upadkiem doskonale panował nad niższymi stworzeniami, donum perfecti domini. Znowu: opinio communis. 7) Swiat był przed pierworodnym upadkiem inaczej urządzony niż dzisiaj: istniała mianowicie głęboka harmonia między człowiekiem, zwierzętami i wszystkimi częściami świata materialnego. Tę interpretację stanu sprawiedliwości pierwotnej podzielali poważni autorowie nie tylko piszący przed ostatnią wojną światową, np. Fr. Diecamp ${ }^{1}$, ale także tuż przed. II soborem watykańskim, np. M. Schmaus ${ }^{2}$.

Należy zauważyć, że tylko dar pozaprzyrodzony nieśmiertelności jest, powszechnym zdaniem, przedmiotem dogmatycznego nauczania Kościoła. W sprawie daru niewinności mają ci teologowie słuszność, gdy twierdzą, że nie jest treścią dogmatyczną; a nie mają racji i wieloznacznie określają jego stosunek do dogmatu, gdy mówią, że jest bliski wiary zamiast powiedzieć, że jest koniecznym wnioskiem z dogmatu, czyli teologicznie naukowo pewne. Należy także pamiętać, że teza przyjmowana przez ogół teologów nie jest tym samym co teologicznie naukowo pewna: bo teologicznie pewna staje się dopiero wtedy, gdy jest w sposób cczywisty na podstawie przesłanek objawionych udowodniona, a przez ogół teologów bywają niekiedy przyjmowane twierdzenia tylko prawdopodobne - czyli niepewne — z braku rozwiązania pewnego. Twierdzenia przyjmowane przez ogół teologów, opiniones communes, nie mogą zatem być umieszczone wśród naukowo teologicznie pewnych, lecz

1 Fr. Diecamp, Theologiae dogmaticae manuale, Paris 1933, vol. II, s. 139 nn.

2 Katolische Dogmatik. Również staroluterańska teologia przyjmowała w stanie nieskażoności status integritatis: świętość oraz doskonałe poznanie Boga i świata jako perfectiones principales; a wolność od cierpień, nieśmiertelność i panowanie nad ziemią - jako perfectiones minus principales. 
wśród teologicznie prawdopodobnych. Ostatnie, siódme twierdzenie tradycyjnej interpretacji jest podsumowaniem sześciu pozostałych i moca zasady peiorem partem sequatur jest również tylko prawdopodobne.

\section{PYTANIA DO ROZWIAZZANIA}

$\mathrm{Na}$ podstawie stopni pewności siedmiu twierdzeń, składających się na interpretację tradycyjną, możliwości nowej interpretacji kształtuja się następująco: pięć twierdzeń teologicznie prawdopodobnych wprost z natury prawdopodobieństwa na tę możliwość wskazują; naukowa pewność omylna twierdzenia o istnieniu daru niewinności w swej naturze zawiera możliwość błędu w tradycyjnej ocenie i przez to samo otwiera możliwość innej interpretacji. Tylko treść tradycyjnej nauki o darze nieśmiertelności musi być zachowana bez najmniejszej zmiany w każdej nowej interpretacji teologicznej, jeśli jest istotnie prawdą, że jest ona treścią dogmatycznie zdefiniowaną. To jest pierwszy powód, ze względu na który zagadnienie nieśmiertelności człowieka przed upadkiem posiada kluczowe znaczenie dla interpretacji dogmatycznej nauki o stanie sprawiedliwości pierwotnej.

Drugi leży w tym, że dar nieśmiertelności jest najbardziej podstawowy w całym zespole darów pozanaturalnych, przyjmowanych przez tradycyjną interpretację. Jeśli bowiem człowiek był nieśmiertelny, to musiał być wolny od chorób i cierpień, które powodują śmierć — stąd stan szczęśliwości; musiał tak panować nad przyrodą, by mu ona nje zagrażała - stąd dar doskonałego panowania; musiał mieć wiedzę, bez której to doskonałe panowanie byłoby niemożliwe - stąd dar doskcnałej wiedzy. Jedynie dar niewinności, należący do porządku moralnego, nie jest następstwem daru nieśmiertelności. Tradycyjna interpretacja miała zatem poważne racje, by razem z nieśmiertelnością przyjąć również dar wolności od chorób i cierpień, dar doskonałej wiedzy i doskonałego panowania nad przyrodą; przez ,poważne racje” nie należy jednak rozumieć dowodów całkowicie oczywistych i przekonywujących.

Podwójnie kluczowa rola nieśmiertelności w interpretacji dogmatycznej nauki o stanie sprawiedliwości pierwotnej spowodowała naprzód, że w poprzednim referacie zostało postawione i rozwiązane pytanie, czy posiadanie jej przez człowieka przed upadkiem jest treścią dogmatycznie zdefiniowaną. Odpowiedź brzmiała: w świetle trydenckiej definicji dogmatycznej nieśmiertelność ta nie tylko nie jest treścią dogmatycznie zdefiniowaną, ale nawet nie jest nauką Kościoła, lecz tylko teologiczną interpretacją. Ta odpowiedź, naukowo omylnie pewna, została ściślej scharakteryzowana jako psychologicznie pewna, a epistemologicz-nie tylko prawdopodobna. Lecz dekrety trydenckie nie są całym nau- 
czaniem Kościoła, a źródłem nauczania kościelnego jest Pismo św. Dlatego obecnie rozważania idą o krok dalej i stawiają pytanie:

Czy w dokumentach Magisterium oraz w Piśmie sw. są wystarczajace podstawy do tego, by twierdzić, że nieśmiertelność człowieka przed upadkiem jest istotnie przez Boga objawiona, formaliter revelata, i dlatego stanowi istotny składnik teologicznej interpretacji dogmatu istnienia sprawiedliwości pierwotnej?

$\mathrm{W}$ osnowie pytania jest widoczne jego założenie metodologiczne. Jest mianowicie sprzeczne $\mathrm{z}$ metodą teologii katolickiej postępowanie tych, którzy po stwierdzeniu, że jakieś twierdzenie nie jest dogmatem, od razu je odrzucają. Albowiem dla katolickiego teologa Magisterium jest wprawdzie normą bliską, ale Objawienie jest normą zasadniczą, do której należy sprowadzić treść nauczania kościelnego. Treść objawienia rozstrzyga ostatecznie o tym, co teologia winna twierdzić a czemu zaprzeczyć.

\section{SENS TRADYCYJNEJ INTERPRETACJI}

Dar nieśmiertelności jest tylko najważniejszą częścią składową trãdycyjnej interpretacji, która wyraża się, jak wykazano wyżej, w siedmiu twierdzeniach. Ostatnie $\mathrm{z}$ nich, tj. siódme, nie tylko jest wnioskiem z pozostałych sześciu, ale odsłania zarazem ich głębszy sens. Jeśli wszystkie sześć twierdzeń są prawdziwe, to z koniecznością wynika, że świat, w którym żył człowiek przed upadkiem, był inaczej urządzony niż świat dzisiejszy. Człowiek nie był wówczas zagrożony przez przyrodę, bo nad nią doskonale panował. Nie był zagrożony przez choroby i cierpienia, bo był od nich wolny. Nie był zagrożony przez drugiego człowieka, bo człowiekiem nie miotała wówczas ani nienawiść ani zazdrość ani namiętność seksualna. Naczelną cechą ówczesnego świata była doskonała harmonia między przyrodą a człowiekiem; doskonała harmonia w samym człowieku, bo dusza przez dar nieśmiertelności doskonale panowała nad ciałem, a rozumna wola przez dar niewinności nad wszystkimi poruszeniami zmysłowymi; wreszcie harmonia między Bogiem a człowiekiem, którego wola przez dary łaski uświęcającej poddana była Bogu.

Ale urządzenie ówczesnego świata, którego obraz rysuje tradycyjna interpretacja, nie było przyrodzone, lecz pozaprzyrodzone; nie wypływało z natury i z własnych sił jestestw, które się na niego składały, ale pochodziło z nadzwyczajnej interwencji Boga i wynikało z darów sposobów nadprzyrodzonych, tj. nieśmiertelności, niewinności, wolności od chorób i cierpien, doskonałej wiedzy, doskonałego panowania nad przyrodą. To „cudowne” urządzenie świata było dla ówczesnego człowieka 
szczególnym dowodem bliskości i dobroci Boga. Ponieważ jednak było „cudowne”, nie było ciągłości między nim a poprzedzającą, naturalną historią świata i nie ma jej z obecną strukturą: ówczesna struktura była więc niezwykła i wyjątkowa.

Obraz świata, w którym żył człowiek przed upadkiem, jest zatem w tradycyjnej interpretacji antyewolucyjny. Albowiem struktura tegoż świata nie tylko nie była wynikiem uprzedniego rozwoju świata, ale nawet nie mogła nim być, jako sposobowo nadprzyrodzona. $\mathrm{W}$ tej interpretacji jest również antyewolucyjny obraz człowi eka. Wyklucza bowiem jego postęp i rozwój naprzód w dziedzinie poznania, gdyż przyznaje mu wiedzę tak doskonałą, że zdaniem św. Tomasza człowiek przed upadkiem poznawał wszystko, do czego kiedykolwiek dojdzie jakakolwiek nauka. Na polu etycznym zaś zamiast ciągłego dążenia do coraz większej świętości wprowadza zachowawczą statyczność: człowiek jest od razu doskonale niewinny, a starać się ma tylko o to, by świętości, którą już ma, nie utracił przez nieposłuszeństwo wobec przykazania Bożego.

Wynika stąd, że egzystencja człowieka przed upadkiem miała - według tradycyjnej interpretacji nie tylko inny sens niż ma obecnie, ale uboższy niż obecnie. Obecnie bowiem po to człowiek żyje na świecie i tylko jeden raz żyje, aby własnym dobrowolnym wysiłkiem możliwie najbardziej rozwinąć swą osobowość, osiągnąć możliwie największą świętość, a przez to zapewnić sobie możliwie największe szczęście wieczne w niebie. Życie na ziemi jest obecnie wezwaniem i zarazem okazją do nieograniczonego zamanifestowania wartości własnej osobowości; w tym leży jego głęboki sens. Natomiast życie w stanie sprawiedliwości pierwotnej, pojętej według tradycyjnej interpretacji, nie dawało człowiekowi nieograniczonych możliwości ani na polu intelektualnym ani na polu etycznym, bo w dziedzinie poznawczej człowiek bez osobistego wkładu otrzymał od razu całą ludzką wiedzę, a jego powołanie w dziedzinie etycznej ograniczało się do przestrzegania przykazania, od którego Bóg uzależnił zachowanie darów sprawiedliwości pierwotnej. Życie na ziemi nie miało znamion wezwania do heroicznej świętości, jakie ma ohecnie; przez to również i widoki na szczęście wieczne były szczuplejsze niż obecnie.

Ostatnie rozważania nad sensem bytowania człowieka na świecie odsłaniają dwie głębokie trudności teologiczne tkwiące w tradycyjnej interpretacji.

Pierwsza dotyczy stosunku między naturą człowieka a nadprzyrodzonymi darami stanu sprawiedliwości pierwotnej. Powszechna i oczywista w teologii zasada głosi mianowicie, że łaska Boża nigdy nie niszczy natury, której bywa dana, ale ją doskonali. Dzieje się tak dlatego, że praw- 
dziwie jest dobrodziejstwem Boga dla natury; a nie byłaby nim, gdyby ją niszczyła, uszkadzała, ograniczała. Ponieważ dary pozanaturalne są również dobrodziejstwem Boga, wspomniana zasada jest ważna równie: w odniesieniu do nich. Z drugiej strony natura człowieka jest taka, że dopóki żyje na ziemi, ma możność ciągłego doskonalenia się zarówno etycznego jak intelektualnego; w naturze ludzkiej leży możność nieograniczonego postępu w obydwu kierunkach. Wobec tego ani łaska uświęcająca ani dary pozanaturalne w rzeczywistości nie mogły człowiekowi w stanie sprawiedliwości pierwotnej ani odebrać ani ograniczyć naturalnej możności nieograniczonego doskonalenia się etycznego i intelektualnego. Zatem tradycyjna interpretacja, która tę możność ogranicza, jest przynajmniej pod tym względem fałszywa i wymaga przebudowy.

Drugą trudnością jest sprzeczność między zamierzeniami a osiągnięciami. Tradycyjna interpretacja zmierza do tego, by wyraziściej przedstawić wielkość dobroci Boga wobec człowieka, którego stworzył. Z tego między innymi względu przyjmuje obok łaski uświęcającej wszystkie wyliczone dary pozanaturalne. Lecz następstwem takiej interpretacji jest ograniczenie możliwości rożwoju osobowości ludzkiej, która pod tym względem ma większą wartość niż wszystkie dary łaski, że te są dane dla dobra osoby i służą jej. Ostatecznie zatem w tradycyjnej interpretacji Bóg okazuje się mniej miłujący i dobry, albowiem dając dary stanu sprawiedliwości pierwotnej równocześnie ogranicza największą wartość człowieka, tj. jego osobowość. Również ta druga trudność wskazuje na konieczność przebudowy tradycyjnej interpretacji.

\section{NOWE INTERPRETACJE}

Nowe interpretacje wyprzedziły czasowo teologię nowej linii, gdyż zaczęły się pojawiać przed końcem II soboru watykańskiego, a miały swe źródło w trudności pogodzenia naukowego obrazu świata z tym, jaki jest implikowany przez interpretację tradycyjną. Do chronologicznie najwcześniejszych należą tłumaczenia przedstawione przez monachijskich dogmatyków M. Schmausa oraz L. Scheffczyka. Żaden z nich nie zalicza się do teologów nowej linii; M. Schmaus uprawia teologię w stylu międzywojennym, a L. Scheffczyk jest otwartym przeciwnikiem nowej teologii; ale obydwaj z darów sprawiedliwości pierwotnej zachowują tylko jaskę uświęcającą, a dary pozanaturalne albo inaczej interpretują, albo odrzucają, uważając je za utopię. Milczące założenie ich teorii jest następujące: zbawienie dokonuje się wprawdzie na ziemi, ale wewnątrz 1.aszych dusz i historia zbawienia jest właściwie wewnętrznymi dziejami dúsz. Dlatego - właściwie i z zasady — żadna historia zbawienia na ziemi - również pierwotna, przed upadkiem — nie może się rozciągać na 
biologiczny porządek natury. M. Schmaus ${ }^{3}$ odróżnia zatem śmierć, Tod, od umierania, Sterben, tj. bolesnego przeżywania śmierci i twierdzi, że człowiek przed upadkiem podlegał prostemu faktowi śmierci: co wychodzi na to, że właściwie był śmiertelny. „Nieśmiertelność” polegała zaś na tym, że gdyby nie był zgrzeszył, byłby wolny od bolesnego umierania. L. Scheffczyk ${ }^{4}$,interpretuje” zaś nieśmiertelność w ten sposób, że w stanie sprawiedliwości pierwotnej człowiek nie byłby przeżywał śmierci jako katastrofalnego następstwa grzechu: podziela zatem poglądy M. Schmausa.

Teoria M. Schmausa i L. Scheffczyka, głównie dzięki innej niż w tradycji interpretacji nieśmiertelności rysuje obraz świata i człowieka przed upadkiem zasadniczo taki sam jak obecnie po upadku; mimo że sytuację etyczną człowieka przed upadkiem przedstawia jako istotnie lepszą dzięki wolności od grzechu. Ale wiaśnie dlatego, że u początków ludzkości widzi stan człowieka istotnie lepszy niż dzisiaj, ten obraz świata i czło-wieka jest nieewolucyjny.

Po II soborze watykańskim rozpowszechnił się w leologii ewolucyjny obraz świata i człowieka. Jego istota polega na tym, że wszystkie byty doskonalsze i bardziej złożone wywodzą się według niego z wcześniejszych form bytowania, prostszych, ale za to mniej doskonałych. Pokaźna grupa teologów widzi w ewolucyjnym obrazie świata więcej niż hipotezę roboczą, jedną z wielu, i faktycznie podnosi go do rzędu aksjomatu, pewnika oraz zasady teologicznego tłumaczenia; teologiczne tłumaczenie musi być z nim tak samo zgodne jak z prawem niesprzeczności. Jeśli przekaz.y objawienia w swym przedmiotowym znaczeniu słownym są sprzeczne z ewolucyjnym obrazem świata, należy je inaczej interpretować; nadać im inne znaczenie niz w tradycyjnej wykładni. W ten sposób podniesienie ewolucyjnego obrazu świata do roli aksjomatu zmusza albo do uprawiania teologii nowej linii albo przynajmniej do egzegetycznych manipulacji na przekazach objawienia.

Takie zastosowanie ewolucyjnego obrazu świata do teologicznego tłunaczenia pierwotnego stanu ludzkości stwierdzamy przede wszystkim u teologów nowej linii. Wśród nich na szczególną wzmiankę zasługują: A. Hulsbosch z dziełem Die Schöpfung Gottes (Freiburg 1965), przede wszystkim zaś P. Schoonenberg, autor słynnej Theologie der Sünde (Einsiedeln 1966). Stosują go również teologowie nie należący do nowej linii, np. profesorowie Gregorianum w Rzymie: Z. Alszegy oraz M. Flick ${ }^{5}$, a nawet bibliści, jak P. Grelot ${ }^{6}$. Dla przedstawicieli tego kierunku nie

3 Das Paradies. Münchener Universitätsreden, 1965, 26.

4 Adams Sündenfall, Wert und Wahrheit, 1965, 761nn.

5 Por. ich studium: Il peccato originale in prospettiva evolutionistica. „Gregorianum", 1966, 201-225.

6 Réflexions sur le problème du péché originel. „Nouvelle Revue Théologique”, 1967, 337-375; 449-484. 
tylko przyznanie darów pozanaturalnych $-\mathrm{z}$ nieśmiertelnością na czele - człowiekowi w pierwotnym okresie historii zbawienia, ale nawet darów łaski uświęcającej jest tak sprzeczne $z$ ewolucyjnym obrazem człowieka, że w ich teoriach nie ma miejsca ani na dary sprawiedliwości i świętości ani na żadne dary pozanaturalne. A ponieważ - jak powiada P. Schoonenberg - objawienie tego przyznania od nas nie wymaga, dlatego zarzucają całą tradycyjną naukę o stanie sprawiedliwości pierwotnej, łącznie z jej podstawową treścią, zdefiniowaną dogmatycznie. Ich interpretacja nie może być zatem uważana za katolicką.

\section{NAUKA KOŚCIOEA}

Wyniki analiz są więc następujące. Tradycyjna interpretacja dogmatu istnienia stanu sprawiedliwości pierwotnej wymaga koniecznie przebudowy; najnowsza zaś, ewolucjonistyczna interpretacja, jest niekatolicika. Stąd pytanie: Jaka jest właściwa, katolicka oraz naukowo teologicznie zadowalająca interpretacja tego dogmatu?

Rozważania obecne nie są w stanie przedstawić całości nowej interpretacji, albowiem jeden referat nie wystarcza na gruntowny i metodologicznie poprawny jej wykład; do tego byłaby nieodzowna monografia składająca się z wielu rozdziałów. Nie wolno nam także uciekać się do pobieżnego szkicu; byłoby to sprzeczne z celem sympozjum, którym jest pokazanie metody dochodzenia do nowej interpretacji. Z tych względów analizy obecne zajmą się węzłowym zagadnieniem nieśmiertelności człowieka przed upadkiem, którego metodycznie poprawne i katolickie rozwiązanie jest nieodzownie koniecznym wstępem do każdej nowej interpretacji tego dogmatu.

Uprawiając teologię katolicką wprost i bezpośrednio badamy treść naüki Kościoła, a na drugim miejscu jej źródła. Już ustaliliśmy w poprzednim referacie - z psychologiczną pewnością a epistemologicznym prawdopodobieństwem - że nieśmiertelność człowieka przed upadkiem w świetle trydenckiego dekretu o grzechu pierworodnym nie jest ani treścią dogmatycznie zdefiniowaną ani przedmiotem nauczania kościelnego. Ustaliliśmy również, że nie jest ona także nauką II synodu z Orange 529. Ale zagadnieniem śmierci i nieśmiertelności przed upadkiem zajmuje się jeszcze synod kartagiński 418 r. oraz Pawła VI Credo narodu Bożego z 30 VI 1968 r.

Synod kartagiński 418 r., w kanonach od drugiego do ósmego, potępia błędy pelagiańskie w sprawie łaski i grzechu pierworodnego. A kanon pierwszy ma na oku herezjarchę Celesiusza, jego słowa przytacza i potępia: „Placuit omnibus episcopis... in sancta Synodo Carthaginensis Ecclesiae constitutis: ut quicunque dixerit, Adam primum ho- 
minem mortalem factum, ita, ut, sive peccaret sive non peccaret, moreretur in corpore, hoc est de corpore exiret non peccati merito, sed necessitate naturae, anathema sit" (DS 222) ${ }^{7}$. Dwie rzeczy nie ulegają wątpliwości; mianowicie, że kanon przytoczony został, razem z następnymi siedmiu, zatwierdzony przez papieża Zozyma i że nie jest nieomylną definicją dogmatyczną. Poza tym jest niejasne, co właściwie w napiętnowanym zdaniu synod potępia; dlaczego potępia; czego przez to potępienie zamierza dokonać; jaki jest związek tego kanonu z następującymi siedmiu. Cały kłopot pochodzi stąd, że synod nie wyraża swej myśli własnymi słowami, ale czyni to sposobem podwójnie pośrednim: przez zapożyczone słowa i przez ich napiętnowanie.

Pozornie wydaje się, że synod chce w tym kanonie opowiedzieć się za nieśmiertelnością człowieka przed upadkiem; definiuje nawet ściśle i metafizycznie tę śmierć, o której mówi: umrzeć - powiada — znaczy rozłączyć się od ciała. Nic więc dziwnego w tym, że tradycyjna dogmatyka katolicka widziała w tym kanonie wyraz nauki Kościoła, że człowiek przed upadkiem posiadał dar nieśmiertelności. Rzecz przedstawia się jednak inaczej po gruntownym przeanalizowaniu kanonu.

Ponieważ swą myśl wyraża synod kartagiński w formie potępienia, wydawać się może, iż właściwym sformułowaniem jego zamysłu będzie zaprzeczenie twierdzenia Celestiusza. Niestety ta metoda zupełnie zawodzi w odniesieniu do kanonu pierwszego, albowiem przez jego zaprzeczenie: 1) opuszczamy teren wiary i przechodzimy na pole teologii; 2) stawiamy nonsensowne twierdzenie; 3) zacieramy związek między kanonem pierwszym i pozostałymi. Przez zaprzeczenie Celestiuszowego twierdzenia otrzymujemy bowiem zdanie: homo non est factus mortalis ita, ut necessitate naturae moreretur, sive peccaret sive non peccaret. Sens jego może być tylko następujący. Człowiek został przez Boga stworzony w takim stanie, że był wolny od naturalnej konieczności umierania; czyli jego natura posiadała przymioty, jakich nie posiada po upadku. Otóż gdyby synod chciał wyrazić taką właśnie naukę, dokonałby teologicznego tłumaczenia objawionych faktów, zamiast prostego ich przekazywania i strzeżenia, czyli przekroczyłby granice swej misji. Ponadto uprawiałby złą teologię, albowiem stan człowieka przed upadkiem równałby ze stanem zmartwychwstałych po sądzie ostatecznym. Ci będą istotnie wolni od naturalnych konieczności wynikających z posiadania ciała; od konieczności pokarmu i napoju, a więc i od konieczności śmierci. Ale taki stan jest nie do pogodzenia z tym co Pismo św. mówi o człowieku przed upadkiem.

7 „Spodobało sį̨ wszystkim biskupom... zgromadzonym na świętym synodzie kościoła kartagińskiego: że ma być wyklęty każdy, kto by twierdził, że Adam pierwszy człowiek został uczyniony śmiertelny tak, że czy by zgrzeszył czy by nie zgrzeszyl byłby umarł, to znaczy opuściłby ciało, nie z winy grzechu ale z konieczności naturalnej". 
Bóg kazał mu nie tylko uprawiać raj, ale i spożywać wszystkie owoce z wyjątkiem drzewa wiadomości. Wreszcie jeśli przyjmiemy to znaczenie kanonu pierwszego, nie widać żadnego logicznego związku z następnymi, mówiącymi o łasce, a zwłaszcza z kanonem drugim, dotyczącym grzechu pierworodnego.

Do niewielu rzeczy pewnych, jakie można powiedzieć o pierwszym kanonie, należy to, że Ojcowie synodu kartagińskiego musieli widzieć związek logiczny między treścią kanonu drugiego a tą, którą chcieli wyrazić w pierwszym. Skoro poprzez zaprzeczenie zdania Celestiusza nie można dojść do odkrycia tego związku ani do ustalenia zamysłu synodu, należy zbadać jego oryginalną postać metodą podstawienia wypadku szczegółowego w miejsce ogólnego twierdzenia. Ogólna wypowiedź Celestiusza odnosiła się niewątpliwie również do konkretnej, historycznej smierci Adama. Zdanie Celestiusza, zastosowane do niej przybiera taką postać: Adam mortalis factus est ita, ut mortuus sit necessitate naturae non merito peccati. Adam został stworzony śmiertelny tak, że umarł z naturalnej konieczności, a nie $\mathrm{z}$ winy grzechu. Poprzednik $\mathrm{w}$ tym zdaniu nie mógł być właściwym powodem napiętnowania, gdyż wtedy synod jak wykazano wyżej - przeszedłby od strzeżenia depozytu wiary do uprawiania teologii. Na pewno zaś mógł być nim następnik, czyli zdanie skutkowe: ,umarł z naturalnej konieczności, a nie z winy grzechu”. Synod chciał więc przez potępienie Celestiuszowego twierdzenia wyrazić myśl, że śmierć, zarówno Adama jak nasza, jest skutkiem grzechu. Taka zaś myśl jest nie tylko zgodna z stałą nauką Pisma św, ale stanowi przygotowanie do kanonu drugiego, który mówi o grzechu pierworodnym i cytuje Rzym 5, 12 o śmierci jako następstwie grzechu: zatem tę w y kładnię należy uznác za najprawdopodobniejszą.

Jest bowiem nieprawdopodobne, by synod chciał również wyrokować o hipotetycznej możliwości, co by było, gdyby Adam nie był zgrzeszył; nie wiąże się ona bowiem logicznie z tematem synodu i z przedmiotem drugiego kanonu. Zajmowanie się nią byłoby już uprawianiem teologii, a nie strzeżeniem i wyjaśnianiem depozytu wiary. Wreszcie, tę hipotetyczną możliwość pominęło w swym nauczaniu Magisterium, bo zupełnie o niej milczy synod z Orange $529 \mathrm{r}$. oraz sobór trydencki; a zasada analogiae fidei, tj. wewnętrznej niesprzeczności i harmonii obowiązuje nie tylko w odniesieniu do Pisma św., ale i do Tradycji. Byłoby rzeczą niewytłumaczalną, gdyby o niej wyrokował synod w Kartaginie, a zupełnie milczał tak II synod z Orange jak przede wszystkim definicja dogmatyczna soboru trydenckiego, zajmujące się ex professo stanem sprawiedliwości pierwotnej.

Wyniki analiz przedstawiają się następująco: Omylne orzeczenie synodu kartagińskiego 418 r. nie mówi wprost o nie- 
śmiertelności człowieka przed upadkiem, ale potępia twierdzenie Celestiusza. Potępione zdanie jest zaś tak zbudowane, że tylko logiczny związek z kanonem drugim pozwala na ustalenie, czego właściwie synod chciał dokonać. W tym świetle synodalna nauka kanonu pierwszego brzmi: Smierć Adama i nasza jest następstwem grzechu. Nie ma natomiast nie tylko pewności, ale nawet prawdopodobieństwa, by synodalną nauką było również, że Adam nie byłby umarł, gdyby nie był zgrzeszył.

Credo narodu Bożego zajmuje się grzechem pierworodnym i stanem sprawiedliwości pierwotnej w artykule 9. Paweł VI wyznaje w nim wiarę w to, że w stanie, w jakim ludzka natura, ,znajdowała się na początku u naszych pierworodziców... człowiek był wolny od zła i od śmierci, homo expers erat mali et mortis" ${ }^{8}$. Przy tym odwołuje się wyraźnie do dekretów trydenckich o grzechu pierworodnym, które interpretuje tak samo, jak tradycyjna teologia, razem z którą podziela tezę, że natura ludzka została zraniona przez pierworodny upadek. Stan sprawiedliwości pierwotnej był więc lepszy od tego, w jakim się obecnie ludzie rodzą. albowiem człowiek posiadał w nim nie tylko sprawiedliwość i świętość zasadzającą się na posiadaniu łaski, ale także był wolny od śmierci i zła. To sformułowanie nie jest całkowicie jednoznaczne. Tylko znaczenie części drugiej nie sprawia żadnej wątpliwośc i: przez wolność od śmierci Paweł VI na pewno rozumie wolność od zagrożenia przez śmierć czyli warunkową nieśmiertelność w znaczeniu szerszym, opartą na obietnicy Bożej. Natomiast wolność od zła jest dw u znaczna: może oznaczać tak wolność od zła bytowego jak od zła moralnego; w pierwszym wypadku chodzić będzie o wolność od cierpienia, w drugim o wolność od grzechu, czyli o świętość. Gdybyśmy przyjęli, że chodzi o wolność od cierpienia, znaczyłoby to bezpośrednio, że Pawłowe Credo przedstawia stan sprawiedliwości pierwotnej równiėz jako stan szczęśliwości. Pośrednio zaś oznaczałoby, że Paweł VI - wbrew swemu wyraźnemu oświadczeniu - faktycznie wyszedł poza tradycyjna interpretację dekretów trydenckich i do poziomu wiary chce podnieść opinię, której tradycyjna teologia nigdy nie uważała za zdefiniowaną dogmatycznie. Trudno przypisać Pawłowi VI tak rażącą niekonsekwencję i dlatego należy przyjąć, że raczej chodzi o wolność od grzechu jako skutek posiadania darów łaski, stanowiących istotę sprawiedliwości pierwotnej.

8 ,Credimus omnes in Adam peccavisse; quod significat originalem culpam ab illo commissam effecisse, ut natura humana, universis hominibus communis, in talem laberetur statum, in quo illius culpae consequentias pateretur. Qui status jam ille non est in natura humana initio in protoparentibus nostris, utpote in sanctitate et justitia constitutis, inveniebatur, et in quo homo expers erat mali et mortis. Itaque haec humana natura sic lapsa, gratiae munere destituta, quo antea erat ornata, in ipsis suis naturalibus viribus sauciata atque mortis imperio subjecta, omnibus homi nibus traditur; qua quidem ratione omnis homo nascitur in peccato. Tenemus igitur, 
Stopień pewności swego Credo określił negatywnie sam Paweł VI, oświadczając w wstępie, że nie jest ono definicją dogmatyczną w znaczeniu właściwym. Znaczy to, że jeśli jakieś twierdzenie nie zostało już gdzie indziej zdefiniowane, nie stało się dogmatem wiary przez to, że jest treścią Pawłowego Credo. Pozytywne zaś określenie stopnia pewności wynika z celu, jaki Paweł VI chciał osiągnąc przez nie. Było nim: ,utwierdzić w wierze braci naszych"; czyli utrzymać ich wiarę - jeśliby słabła lub groziły jej błędy — w takiej samej mocy, jak była przedtem. Wynika stąd reguła ogólna. Jeśli jakieś twierdzenie Credo zostało zaczerpnięte z wcześniejszych dokumentów Magisterium, zachowuje w Pawłowym Credo ten sam stopień pewności, jaki ma w dokumencie, z którego zostało wzięte. Jeśli zaś nie zostało zapożyczone z żadnego wcześniejszego aktu Magisterium, lecz jest oryginalną własnością Pawłowego Credo, jest bezpieczne dla wiary - i teologicznie prawdopodobne - a jego zaprzeczenie jest dla wiary niebezpieczne ${ }^{9}$. Zastosowanie tych zasad oceny stopnia pewności do zagadnienia nieśmiertelności w Pawłowym Credo daje następujące wyniki.

1) O cielesnej nieśmiertelności człowieka przed upadkiem Pawłowe Credo mówi równoznacznie, ale tak jasno, że z całą pewnością było zamierzeniem Pawła VI, by wszyscy wierni tę naukę przyjęli tak, jak na to zasługuje.

2) Nauczanie wprost i bezpośrednio o tej nieśmiertelności jest własnością Pawłowego Credo, albowiem przedtem nie było przedmiotem żadnego dokumentu nauczycielskiego Kościoła. W moim poprzednim referacie zostało udowodnione, że ani sobór trydencki ani II synod z Orange nie zajmują się zagadnieniem śmierci i nieśmiertelności człowieka przed upadkiem. Przeprowadzone zaś wyżej analizy wykazały, że o ile można coś określonego i ścisłego powiedzieć o sensie kanonu I, zamierzonym przez Ojców synodu w Kartaginie 418 r., to dotyczył on obecnego porządku rzeczy i śmierci jako kary za grzech, a nie sytuacji człowieka przed grzechem.

3) Posiadanie cielesnej nieśmiertelności przez człowieka przed upadkiem jest wobec tego nauką Kościoła tylko bezpieczną dla wiary i teologicznie prawdopodobną, a jej zaprzeczenie jest dla wiary niebezpieczne.

Concilium Tridentinum secuti, peccatum originale, una cum natura humana, transfundi propagatione, non imitatione idque inesse unicuique proprium".

9 O zadaniach bezpiecznych dla wiary i ich teologicznym prawdopodobieństwie mówi szerzej moja: Metodologia teologii dogmatycznej, Kraków 1947, 339-345. Por. także moje: Pawtowe „Credo narodu Bożego" w Nurcie zagadnień posoborowych, Warszawa 1969. 
Tradycyjna dogmatyka tylko dlatego mogła twierdzić, że jest ona dogmatem wiary, że egzegetowała dokumenty Magisterium niehistorycznie, tzn. w oderwaniu od konkretnych pytań, na które odpowiadały. Niehistoryczne podejście narażało ją na niedostrzeżenie właściwego zamysłu Kościoła, od którego jedynie i ostatecznie zależy, co jest i co nie jest dogmatycznie definiowane. A Paweł VI nie działał bezpodstawnie, gdy w swym Credo włączył nieśmiertelność przed upadkiem do nauki Kościoła, szczególnie w dniu dzisiejszym aktualnej. Nie opierał się bowiem wyłącznie na tradycyjnej interpretacji dokumentów kościelnego nauczania, ale również na nauce Pisma św. o śmierci jako skutku grzechu, dla której nie mają miejsca ewolucjonistyczne teorie początków ludzkości, które tę nieśmiertelność odrzucają. Miał więc prawo uznać odrzucenie nieśmiertelności za niebezpieczne dla wiary, a nieśmiertelność za bezpieczną.

Po dotychczasowych rozważaniach można udzielić odpowiedzi na pierwszą część pytania, jakie zostało postaw i o n e do rozwiązania: Wprawdzie Credo narodu Bożego, wśród dokumentów Magisterium, w sposób prawdopodobny wskazuje na to, że nieśmiertelność człowieka przed upadkiem jest istotnie przez Boga objawiona; ale dopuszcza tę możliwość, że nie jest istotnie objawiona, czyli nie musi być składnikiem każdej katolickiej interpretacji teologicznej dogmatu istnienia stanu sprawiedliwości pierwotnej.

Będzie $\mathrm{z}$ wielkim pożytkiem dla nowej interpretacji dogmatu, jeśli dodamy to, co nie jest wprost zagadnieniem postawionym do rozwiązania, ale zostało poruszone w tym samym, 9. artykule Pawłowego Credo. Wolność od zła, jaką ono przypisuje człowiekowi przed upadkiem, oznacza wolność od grzechu, czyli świętość; nie ma wystarczających podstaw do tego, by należało ją rozumieć jako wolność od cierpień czyli jako stan szczęśliwości.

\section{EPISTEMOLOGICZNE I ETYCZNE NASTEPSTWA STANOWISKA KOSCIOEA}

Następstwa epistemologiczne dotyczą teologii i jej metody, a etyczne - człowieka, który uprawia teologię. Powinności etyczne mają swe źródło w katolickiej wierze i mają za przedmiot nie to, co w nauce Kościoła jest dogmatem, ale również to, co jest tylko bezpieczne dla wiary i teologicznie prawdopodobne. W naszych rozważaniach chodzic będzie konkretnie o powinności epistemologiczne i etyczne w stosunku do takiej właśnie nauki o nieśmiertelności przed upadkiem pierworodnym.

Kto posiada katolicką wiarę i bierze ją poważnie, ten uznaje, że Kościół ma nie tylko misję, ale i opiekę Ducha Św. do tego, by strzegł i nie- 
omylnie wyjaśniał naukę objawioną. Jeśli więc Kościół orzeka, że jakieś twierdzenie jest dla katolickiej wiary niebezpieczne, tylko ten postąpi zgodnie ze swą katolicką wiarą, kto uzna również i to, że Kościół miał w tym wypadku podstawy uzasadniające takie orzeczenie. Sprzeczne z katolicką wiarą byłoby nastawienie wrogie wobec takiego orzeczenia, a więc jego odrzucenie, jego zwalczanie. Ponieważ te wymagania wypływają z natury wiary, dotyczą przede wszystkim aktów wewnętrznych, tak że czysto zewnętrzne posłuszeństwo - przy równoczesnym buncie wewnętrznym - nie czyni zadość tej powinności uznania.

$\mathrm{Z}$ natury katolickiej teologii wynikają analogicznie epistemologiczne powinności w stosunku do metody badań. Przedmiotem właściwym badań w katolickiej teologii jest treść nauki Kościoła i teologia jest katolicka, jeśli zakłada określenie swego przedmiotu przez Magisterium. Wobec tego musi przyjąć jako przedmiotową rzeczywistość, którą ma badać, uznanie danego twierdzenia za niebezpieczne dla wiary. Nieuznanie, odrzucenie, zwalczanie tego faktu byłoby zaprzeczeniem katolickości teologii. Z drugiej strony jednak teologia — dlatego że jest nauką — ma powinność wszechstronnego i całkowicie obiektywnego przebadania stosunku tego twierdzenia do źródeł objawionych i do reszty nauki Kościoła.

Z obydwu tych spojrzeń równocześnie wynikają cztery następujące twierdzenia. Jeżeli Kościół uzna jakieś twierdzenie za niebezpieczne dla wiary, to - po pierwsze - tak człowiek wierzący jak teologia katolicka obowiązani są uznać stanowisko Kościoła. Po drugie - zwalczanie stanowiska Kościoła jest sprzeczne tak z katolicką wiarą jak z naturą kato-lickiej teologii. Po trzecie - człowiek wierzący ma możność, a teologia powinność obiektywnego i wszechstronnego przebadania tego twierdzenia. Czwarte - tak wiara jak natura teologii dozwala katolickiemu teologowi opowiedzieć się za twierdzeniem przeciwnym stanowisku Kościoła, jeśli: a) przeprowadził gruntowne i całkowicie obiektywne badania; b) posiada wystarczająco silne argumenty przeciwko stanowisku Kościoła; c) jeśli swoje twierdzenie uzna za omylne i epistemologicznie tylko prawdopodobne; d) jeśli gotów jest podporządkować się ostatecznemu rozstrzygnięciu Kościoła, który — dzięki asystencji Ducha \$w. wyjaśnia objawienie nieomylnie i ponadnaukowo. Gdyby się natomiast opierał przy swym zdaniu tak, że nie chciałby się podporządkować zdaniu Kościoła, z jednej strony dałby dowód, że przecenia wartość teolngicznego poznania i nie dostrzega jego granic oraz słabości, a z drugiej grzeszyłby przeciw wierze dlatego, że dobrowolnie wystawia się na niebezpieczeństwo zaprzeczenia wierze, podtrzymując z uporem twierdzenie dla wiary niebezpieczne.

$\mathrm{Z}$ tych reguł, przyjętych tak przez Kościół nauczający jak i przez 
tradycyjną teologię ${ }^{10}$, wypływają następujące w y tyc zne d la naszych dalszych rozważań:

1) Zarówno wiara szukająca rozumienia, fides quaerens intellectum, jak i teologia, która z niej bierze początek, każe tak ściśle przebadać naukę Pisma św., jak przeanalizowano wyżej naukę Magisterium, Tradycji. Analizy przeprowadzone wyżej wykazały, że w sprawie cielesnej nieśmiertelności przed upadkiem Pawłowe Credo nie ma dla siebie podstaw we wcześniejszych dokumentach Magisterium. Zgodne stanowisko teologów już doprowadziło do tego, że Kościół przestał uważac poligenizm za niebezpieczny dla wiary. Teologia winna więc dokonać także tej próby, czy precyzyjniejsze przebadanie oraz precyzyjniejsze wyrażenie nauki Pisma św. nie otworzy drogi do zmiany osądu przez Kościół nauki o cielesnej nieśmiertelności człowieka przed upadkiem.

2) Jeśliby się po takich analizach Pisma św. okazało, że rezygnacja z cielesnej nieśmiertelności przed upadkiem jest bezpieczna dla wiary -bo ani wprost nie jest sprzeczna $z$ nauką objawienia ani nie pociąga za sobą jej zaprzeczenia - taki wynik trzeba uważać tylko za epistemologicznie prawdopodobny i tymczasowy. Ostateczny i rozstrzygający głos należy bowiem do Kościoła, który — przy asystencji Ducha Św. ponadnaukowo i nieomylnie orzeknie, czy naukowe analizy Pisma św. odnalazły objawioną prawdę, czy też pobłądziły.

3) Gdyby się po analizach okazało, że rezygnacja z cielesnej nieśmiertelności przed upadkiem jest bezpieczna dla wiary, wynik ten nie może być od razu szeroko rozpowszechniany i przedstawiany jako prawdziwa zdobycz teologicznej nauki. Ponieważ jest omylny, jest epistemologicznie tylko prawdopodobny, a w stosunku do orzeczenia Kościoła tylko tymczasowy; zatem jest bardziej drogą do zdobyczy niż zdobyczą. Ponieważ faktycznie jest niebezpieczny dla wiary, może wywołać nie tylko trudności przeciwko wierze, ale i stać się okazją utraty wiary u tych, którzy nie mają wystarczającego przygotowania - religijnego i naukowego - do jego asymilacji. Teolog, który by ten pogląd rozpowszechniał wobec wszystkich bez żadnej różnicy, ponosiłby moralną odpowiedzialność za kryzys wiary u odbiorców. Dopóki teologowie nie osiągną pełnej oczywistości, a Kościół nie zmieni swego osądu, ten pogląd można w sposób odpowiedzialny przedstawiać tylko tym, którzy mają wystarczające przygotowanie teologiczne, np. profesorom i studentom wyższych szkół teologicznych.

10 Por. J. Różycki: Metodologia tenlogii dogmatycznej, Kraków 1947, 338 nn. 


\section{7. ŚMIERĆ I NIESMIERTELNOSC W KSIĘDZE RODZAJU}

Przystępujemy do rozwiązania drugiej części zagadnienia, postawionego naszym rozważaniom: Czy nieśmiertelność człowieka przed upadkiem pierworodnym jest nauką zamierzoną i wyrażoną przez Pismo św.?

$\mathrm{Na}$ wstępie należy wyjaśnić, o jaką nieśmiertelność chodzi w tym pytaniu. Nieśmiertelność w znaczeniu właściwym polega na wykluczeniu śmierci cielesnej. Jest ona, według teologii, dwojakiego gatunku: istotowa i nieistotowa. Istotowo nieśmiertelnym jest byt, jeśli jego natura wyklucza możność utraty życia, czyli śmierci. W łacińskiej terminologii scholastycznej istotą jej jest: non posse mori. Taką jest nieśmiertelność duszy ludzkiej, której niematerialność uniemożliwia śmierć. Nieistotowo a $\mathrm{z}$ daru Bożego jest nieśmiertelny ten byt, który wprawdzie z natury może umrzeć, ale $z$ daru Bożego posiada moc wykluczającą śmierć na zawsze. Jej istotą jest: non mori. Natomiast nieśmiertelność, jaką teologia i Kościół przypisują człowiekowi przed upadkiem, jest nieśmiertelnością $w$ znaczeniu szerszym - więc niewłaściwym i jej istota wyraża się $\mathrm{w}$ formule: posse non mori, móc nie umrzeć. Jest to tym bardziej niewłaściwe znaczenie, że była to nieśmiertelność warunkowa, bo człowiek przed upadkiem tylko pod tym warunkiem i tylko tak długo mógł nie umrzeć, jak długo zachowywał przykazanie Boże. Mamy więc odpowiedzieć na pytanie, czy człowiek przed pierworodnym upadkiem mógł - według nauki Pisma św. - nigdy nie umrzeć.

Aby na nie odpowiedzieć, trzeba jeszcze ustalić, czym jest ta śmierć, o którą chođzi w nauce o nieśmiertelności przed upadkiem. Otóż zarówno Kościół jak teologia pojmują tę śmierć ontologicznie i formalnie: ontologicznie dlatego, że określają śmierć jako rozłączenie duszy od ciała; a formalnie - z tego względu, że do istoty śmierci nie zaliczają zespołu aspektów, towarzyszących temu rozłączeniu. Natomiast biblijne pojęcie śmierci, zwłaszcza w Starym Testamencie jest nieformalne, bo nie tylko te aspekty włącza do istoty, ale na nich przede wszystkim zasadza istotẹ śmierci. Stąd wypływa ciągła konieczność sprawdzania, czy Pismo św. i teologia mówią o tej samej rzeczy, gdy używają tych samych słów: śmierć, nieśmiertelność.

Wszystkie późniejsze księgi Pisma św. nawiązują do historii raju i upadku Adama i Ewy, przekazanej nam przez dokument jahwistyczny księgi Rodzaju, rozdz. II-III, ilekroć mówią o śmierci i nieśmiertelności. Oto w tłumaczeniu biblii tynieckiej te wiersze dokumentu, które dały podstawę do przypisania człowiekowi przed upadkiem warunkowej nieśmiertelności. Rdz 2, 15: „Jahwe Bóg wziął zatem człowieka i umieścił go w ogrodzie Eden, aby uprawiał go i doglądał. A przy tym Jahwe Bóg dał człowiekowi taki rozkaz: «Z wszelkiego drzewa tego ogrodu 
możesz spożywać według upodobania; ale z drzewa poznania dobra i zła nie wolno ci jeść, bo gdy z niego spożyjesz, niechybnie umrzesz»". Rdz 3, 1: „A wąż był najbardziej przebiegły ze wszystkich zwierząt polnych, które Jahwe Bóg stworzył. On to rzekł do niewiasty: "Czy to prawda, że Bóg powiedział: Nie jedzcie owoców ze wszystkich drzew tego ogrodu?» 2: Niewiasta odpowiedziała wężowi: «Owoce z drzew tego ogrodu jeść możemy, 3: tylko o owocach z drzewa, które jest w środku ogrodu, Bóg powiedział: Nie wolno wam jeść z niego, a nawet ̧o dotykać, abyście nie pomarli». 4: Wtedy rzekł wąż do niewiasty: «Na pewno nie umrzecie! 5: Ale wie Bóg, że gdy spożyjecie owoc z tego drzewa otworzą się wam oczy i tak jak Bóg będziecie znali dobro i zło»”. Rdz 3, 21: „Jahwe Bóg sporządził dla mężczyzny i dla jego żony odzienie ze skór i przyodział ich. 22: Po czym Jahwe Bóg rzekł: «Oto człowiek stał się taki jak My: zna dobro i zło; niechaj teraz nie wyciągnie przypadkiem ręki, aby zerwać owoc także $\mathrm{z}$ drzewa życia, zjeść go i żyć na wieki». 23: Dlatego Jahwe Bóg wydalił go z ogrodu Eden, aby uprawiał tę ziemię, z której został wzięty. 24: Wygnawszy zaś człowieka, Bóg postawił przed ogrodem Eden cherubów i połyskujące ostrze miecza, aby strzec drogi do drzewa życia".

Po przeczytaniu 3, 22-24, a zwłaszcza słów, ,aby zerwać owoc także z drzewa życia, zjeść go i żyć na wielsi", wydaje się, że jest w nich wyrażone równoznacznie, f or ma lite r i m p li cit e, że Adam — jeśliby przebywał w raju - mógłby nigdy nie umrzeć (dzięki spożywaniu owoców z drzewa życia). W słowach Boga odnajdujemy bowiem składniki definicji warunkowej nieśmiertelności, o którą właśnie chodzi. Popełnilibyśmy jednak gruby błąd, gdybyśmy na ich podstawie od razu wnioskowali, że warunkowa nieśmiertelność przed upadkiem jest naukă, którą autor natchniony księgi Rodzaju — i Bóg jako jej autor pierwszo* rzędny - chciał wyrazić i przekazać ludzkości.

Po pierwsze należy pamiętać o tym, że w języku hebrajskim wieczność, 'olam, nie oznacza wieczności ściśle pojętej, ale bardzo długie trwanie. Dopiero dodatkowe wskazówki kontekstu literackiego i rzeczowego, mogą rozstrzygnąć, kiedy chodzi o prawdziwą wieczność bez końca, a kiedy o bardzo długie, ale skończone trwanie. A są uzasadnione wątpliwości, czy bardzo obrazowy i popularny kontekst opowiadania jahwisty domaga się, by wieczność życia Adama musiała być rozumiana w znaczeniu ścisłym. Czy życie bardzo długie, ale nie bez końca, jest prawdziwie nieśmiertelnością? Jeśli zaś ,żyć na wieki” nie oznaczałoby życia bez końca, wtedy groźbę śmierci — „niechybnie umrzesz” — należałoby rozumieć o przyspieszonej śmierci, a nie o śmierci po prostu; czyli tak, jak rozumieją egzegeci niekatoliccy, którzy nie czują się skrępowani dekretem trydenckim o grzechu pierworodnym. Wyrażenie to mia- 
łoby wtedy to samo znaczenie, w jakim się je do dzisiaj używa w sądowych wyrokach śmierci.

Po drugie, to rozumowanie, stosowane powszechnie w dawniejszej teologii, nie bierze zupełnie pod uwagę rodzaju literackiego; naprzód rodzaju literackiego Jahwisty, a potem bardzo swoistego rodzaju literackiego księgi Rodzaju. T' zaś bardzo swoiste rodzaje literackie sprawiają, że nie każdy szczegół, zawarty w znaczeniu słownym dokumentu jahwistycznego, jest poglądem, który jahwista zamierzał przekazać czytelnikowi, i nie każdy zamysł Jahwisty jest zamierzeniem, poglądem i nauką, którą natchniony autor księgi Rodzaju chciał wypowiedzieć. „Rodzaje literackie należy uwzględnić, genera litteraria respicienda sunt" - powiada Konstytucja Dei Verbum (3, 12) II soboru watykańskiego - a to dlatego, że ,w Piśmie św. Bóg mówił przez ludzi i po ludzku".

Pięcioksiąg Mojżeszowy składa się co najmniej z trzech dokumentów - z Kodeksu Kapłańskiego, Dokumentu Jahwistycznego i Deuteronomium, a opis stworzenia i początków ludzkości w księdze Rodzaju podany jest dwukrotnie: w rozdz. I. z Kodeksu Kapłańskiego, w rozdz. IIIII. zaś według dokumentu Jahwistycznego. Ponieważ zagadnienie śmierci i nieśmiertelności znajduje się w jahwistycznych rozdziałach, dlatego trzeba naprzód przeanalizować właściwości jego rodzaju literackiego, wyciągnąc $\mathrm{z}$ nich wnioski dla wykładni tego dokumentu i zgodnie z nimi przeprowadzić egzegezę tych ustępów. To będzie pierwszym etapem naszych poszukiwań. Autor Pięcioksięgu tworzył swe dzieło $\mathrm{w}$ ten sposób, że nie usiłował harmonizować treści dokumentów, by stworzyć jedną zwartą całość, ale ustawiał je obok siebie nie dokonując zmian nawet wtedy, gdy w przedstawieniu szczegółów były między nimi nie tylko różnice, ale i sprzeczności. Jeśli zaś tworzył łącząc dokumenty w jec.no, to ich zawartością chciał się posłużyć dla wyrażenia własnej myśli. Dlatego po ustaleniu zamysłu autora dokumentu jahwistycznego, należy zapytać, jaką naukę zamierzał wyrazić natchniony kompilator księgi Rodzaju. Jest to drugi etap egzegetycznych poszukiwań. Ponieważ wreszcie współczesna hermeneutyka oraz Konstytucja Dei Verbum przyjmują zgodnie zasadę, że „Pismo św. należy w tym samym duchu czytać i wykładać, w jakim zostało napisane" $(3,12)$, trzeci - teologiczny etap egzegezy polegał będzie na rozpatrzeniu nauki wyrażonej przez księgę Rodzaju w świetle całości objawienia Starego i Nowego Testamentu oraz w świetle wykładni Kościoła, który dzięki opiece tegoż Ducha Sw. ma moc nieomylnego wyjaśniania objawionej treści Pisma św.

$\mathrm{P}$ ierwszy etap rozpoczniemy przypomnieniem tego, co $\mathrm{w}$ sprawie rodzaju literackiego Jahwisty jest powszechnie przyjęte i znane. Jeśli chodzi o pradzieje ludzkości i świata, tak Kodeks Kapłański jak 
Dokument Jahwistyczny są etiologią pod postacią historii, to znaczy posługując się literacką formą opowiadania historycznego chcą teraźniejszość wytłumaczyć przyczynowo przez zdarzenia zaszłe w przeszłości. W zakresie tego samego rodzaju jest jednak wielka różnica między Ko-deksem Kapłańskim a Jahwistycznym i te różnice są uderzające w rozdziałach dotyczących pradziejów. Kodeks Kapłański w I. rozdz. Rdz. nie tylko posługuje się pojęciami wolnymi od wszelkich okoliczności i skojarzeń materialnych, np. „na początku stworzył Bóg”, ale nawet wygłasza ogólne twierdzenia o prawdziwie metafizycznym znaczeniu, np. „,wszystko, co uczynił, było bardzo dobre" (I, 31). Tymczasem w jahwistycznyrn opisie pradziejów II. i III. rozdz. Rdz. nie tylko nie ma sformułowanego żadnego twierdzenia ogólnego, ale nawet żadnego pojęcia, oderwanego od konkretnych okoliczności. Jahwistyczny opis pradziejów ogranicza się do przekazania konkretnych faktów, dokonanych przez konkretne osoby, w konkretnych okolicznościach. I tak w słownym i przedmiotowym znaczeniu, in sensu litterali immediato, nie ma mowy ani o niewinności ludzi przed upadkiem, jest tylko przedstawiona ich reakcja na nagość; nie ma mowy o utracie nieśmiertelności, jest tylko opis wypędzenia $z$ raju i zamknięcia dostępu do drzewa życia. Szczęście, niewinność, etyczna prawość, grzech, nieśmiertelność i jej utrata stanowią abstrakcyjne interpretacje konkretnych wydarzen, przekazanych przez jahwistę. Powstaje pytanie, czy dokonując tych abstrakcyjnych interpretacji nie wnosimy do rozumienia tekstu myśli obcych zamysłowi autora Dokumentu, zupełnie przez niego nie zamierzonych.

Nie ulega wątpliwości, że zamysł autora Dokumentu nie zamykał się w ciasnych ramach bezpośredniego znaczenia słownego; chciał on na pewno poprzez ten szereg konkretnych wydarzeń wyrazić jakąś religijna prawdę; co najmniej jedną. Cały szereg konkretnych wydarzeń, jaki mamy w analizowanych rozdziałach Dokumentu, pełniły dla niego rolę języka, w którym wypowiedział religijną prawdę. A jeśli były językiem autora, to muszą być rozumiane jako czyste symbole religijnej prawdy. Gdybyśmy je traktowali realistycznie, tzn. gdybyśmy przyjęli, że wszystkie wydarzenia opisane $w$ Dokumencie wskazują na fakty, które się rzeczywiście dokonały w przeszłości, nie tylko postępowalibyśmy wbrew zamierzeniom autora, ale doszlibyśmy do wniosków, które są nie do przyjęcia na płaszczyźnie chrześcijańskiego pojęcia Boga i Opatrzności. Wtedy bowiem musielibyśmy powiedzieć, że kara Boża na mężczyznę dotyka właściwie tylko rolników; musielibyśmy przyjąć istnienie cherubów, tj. uskrzydlonych istot opiekuńczych; musielibyśmy się zgodzić na to, że spożycie jednego materialnego owocu mogło dać człowiekowi wszechwiedzę i pod tym względem zrównać go z Bogiem.

Ile i jakie prawdy religijne chciał autor Doku- 
mentu wyrazić tym ,językiem” konkretnych wydar z eń Obydwa analizowane rozdziały Dokumentu są - ze względu na rodzaj swego ,,języka" - podobne do dramatów i powieści, w których poprzez dzieje bohaterów - autorowie wypowiadają jakieś tezy filozoficzne, społeczne czy światopoglądowe. Aby wypowiedzieć pogląd, który się da ując w jednym, krótkim zdaniu, potrzebują nieraz setki stron. Np. myśl, którą St. Wyspiański chciał wyrazić w dramacie pt. „Wyzwolenie”, sprowadza się do dwu słów epilogu: „Więzy rwać”. Sprawa przedstawia się podobnie z zamysłem Jahwisty, co do którego dwie rzeczy nie ulegają wątpliwości: 1) przez opis raju i upadku chciał wyrazić przynajmniej jedną myśl; 2) myśli, które chciał wyrazić, jest na pewno mniej niż zda-rzeń przedstawionych $\mathrm{w}$ tych rozdziałach. Tradycyjna interpretacja katolicka przyjmuje bowiem zgodnie, że utrata nieśmiertelności wyrażona została dwoma zdarzeniami: wypędzeniem z raju i postawieniem straży u wejścia do raju.

Wypływają stąd dwie podstaw owe reguły interpretac y j n e: a) Na pewno zamysłem autora Kodeksu Jahwistycznego była ta religijna prawda, na którą wskazuje całość wydarzeń, składających się na opis raju i upadku. b) Jest tylko prawdopodobne, że niektóre grupy wydarzeń mogą wskazywać również na religijne prawdy, które autor Dckumentu zamierzał wypowiedzieć. To zaś oznacza, że im bardziej oddalamy się od całości i rozpatrujemy mniejsze grupy, jest tym mniejsze prawdopodobieństwo odnalezienia w nich nauki zamierzonej przez autora Kodeksu.

Na pewno więc zamysłem autora Kodeksu było przedstawienie nauki o przyczynowym pochodzeniu dobra i zła w życiu ludzkim; i to zarówno zła moralnego jak bytowego. A myśl, którą chciał wyrazić, można wypowiedzieć w następującym twierdzeniu: $\mathrm{Za}$ istnienie zła w życiu ludzkim nie jest odpowiedzialny Bóg, bo od niego pochodzi tylko dobro; zło pojawiło się $\mathrm{w}$ świecie ludzkim $\mathrm{z}$ winy człowieka. Na taki sens wskazuje ogół wydarzeń z II. i III. rozdziału, wśród których przełomowe jest przekroczenie przykazania Bożego. Albowiem do chwili grzechu człowiek z dobroci Bożej ma: raj, w którym może wieść łatwe i szczęśliwe życie; niewinność; żonę podobną i równą sobie; wolność od zagrożenia przez śmierć. Natomiast po grzechu zostaje wypędzony $z$ raju i skazany na ciężką walkę o byt; kobieta nie tylko będzie pod władzą męża ale w swym kobiecym powołaniu, tj. rodzeniu dzieci, będzie miała źródło cierpień; mężczyzna i kobieta są pozbawieni niewinności i muszą umrzeć.

$\mathrm{Z}$ tym podstawowym twierdzeniem związane jest drugie - pokrewne, ale nie równoznaczne, dlatego że dotyczy następstwa czasowego, podczas gdy pierwsze uwzględnia wyłącznie zależności przyczynowe. Oto ono: $z$ winy człowieka nastąpiło pogorszenie stanu 
c z ł o wi eka. Ponieważ wskazuje na nie cały kontekst II. i III. rozdziału, również i ono musi być uznane za naukę zamierzoną i wyrażoną przez Kodeks Jahwistyczny.

A n i eśmi e r tel ln ość? Naprzód nie należy zapominać o trudności filologicznej, wysuniętej na początku rozważań w związku z III, 22. Wobec tego, że tekst oryginalny posługuje się tu wyrażeniem 'olam, które może oznaczać i prawdziwą wieczność bez końca i bardzo długie, ale skończone, trwanie, brak wystarczającej podstawy do tego, by mówić o nieśmiertelności warunkowej w znaczeniu ścisłym, zdefiniowanym na początku tego ustępu. Do tego, by pozostać w zgodzie z tekstem, wystarczy mówić o wolności od zagrożenia przez śmi e r ć; jeśli bowiem jest odsunięta na bardzo odległą przyszłość, praktycznie i aktualnie nie zagraża.

Po wtóre, nawet gdyby w tekście chodziło o nieśmiertelność warunkową w znaczeniu właściwym, to również w tym wypadku nie ma wystarczających podstaw do tego, by ją należało uważać za naukę, którą autor Dokumentu zamierzał wyrazić i przekazać czytelnikom. Albowiem jest ona tylko jednym z szczegółów, składających się na obraz życia przed upadkiem, a zastanawiając się nad rodzajem literackim Dokumentu doszliśmy do wniosku, że na pewno nie wszystkie szczegóły zostały zamieszczone przez autora celem wyrażenia osobnych nauk i jest małe prawdopodobieństwo, by szczegóły stanowiły przedmiot jego właściwego zamysłu. Co więcej, gdyby się jeden szczegół uznało za zamysł autora, trzeba by to samo powiedzieć o innych, np. o drzewie wiadomości. Tą drogą doszlibyśmy do egzegezy dosłownej, która jest nie do przyjęcia. W sumie wszystkie argumenty, razem wzięte, każą uznać za bardziej prawdopodobne, że zagrożenie przez śmierć nie jest przedmiotem właściwego zamysłu jahwisty.

Chociaż Dokument jest w Piśmie św., znajduje się w nim tak jak cytat w książce. Dlatego nie ma podstawy do tego, by twierdzić, że autor Dokumentu pisał pod natchnieniem Ducha Św. Dlatego również nauka Dokumentu tylko wtedy jest nauką Pisma św., jeśli autor księgi Rodzaju przyswoił ją sobie i chciał ją w tej księdze wyrazić.

Drugi etap rozważań egzegetycznych ma za cel udzielić odpowiedzi na pytanie: Czy warunkowa nieśmiertelność człowieka przed upadkiem jest wśród tych nauk, jakie natchniony autor księgi Rodzaju chciał w jej pierwszych trzech rozdziałach wyrazić?

Swój opis stworzenia świata i pradziejów ludzkości zredagował autor natchniony w ten sposób, że w rozdz. I. dał przekaz Kodeksu Kapłańskiego, a w rozdz. II. i III. wersję z Dokumentu Jahwistycznego. Cała księga Rodzaju składa się z poustawianych obok siebie wycinków tych dokumentów. Współcześni kompilatorzy starają się zharmonizować między 
sobą dane zaczerpnięte z różnych źródeł. Autor Genesis postępował zupełnie inaczej. Nie widać u niego żadnej troski o uzgadnianie różnych wersji. Ustępy z różnych dokumentów umieszcza obok siebie bez dokonywania $\mathrm{w}$ nich zmian, mimo widocznych różnic $\mathrm{w}$ przedstawieniu tej samej rzeczy. Widać to na kapłańskiej i jahwistycznej wersji stworzenia człowieka. Według Kodeksu Kapłańskiego stworzenie człowieka dokonało się na końcu, a w Dokumencie Jahwistycznym miało miejsce przed zasadzeniem raju. Umieszcza je obok siebie bez zmian nawet mimo widocznych sprzeczności w szczegółach. Jest to bardzo widoczne w opisie potopu, w którym część jahwistyczna mówi, że Noe zabrał do arki po 7 samców i 7 samiczek zwierząt czystych, a tylko po parze zwierząt nieczystych (Rdz. 7, 2) - a kilka wierszy dalej ustęp wzięty z Kodeksu Kapłańskiego podaje, że ze wszystkich gatunków, tak czystych jak nieczy-stych, wziął tylko po parze (Rdz. 7, 8). Taki sposób komponowania wska-• zuje na to, że autor Genesis nie chciał tworzyć nowej tradycji religijnej, ale istniejące tradycje jak najwierniej zachować i potomności przekazać. Wskazuje również na to, że chciał przekazać tylko to, co stanowiło sedno tradycji religijnej Izraela; natomiast nie chodziło mu zupełnie ani o drugorzędne szczegóły, ani o formę literacką i szatę pojęciowo słowną. Sednem religijnej tradycji są zaś istotne składniki treściowe, wspólne dokumentom, które wcielał do swej księgi. Wobec tego podstawowa reguła interpretacji będzie brzmiała: nauką zamierzoną przez autora natchnionego księgi Rodzaju są na pewno te istotne składniki, które są wspólnym zamysłem dokumentów, z których utworzył tę księgę.

Powstaje pytanie: Co sądzić o składnikach treściowych właściwych tylko jednemu dokumentowi? Jeśli są składnikami drugorzędnymi, np. opisującymi w sposób bardziej szczegółowy to, co drugi dokument przed-stawia zwięźlej, nie stanowią nauki, którą autor chciał wyrazić i przekazać czytelnikom. Jeśli natomiast są istotne dla religijnej tradycji Izraela, prawdopodobnie również i one stanowią naukę zamierzoną przez autora natchnionego. Aby jednak móc ustalić, że są istotnymi składnikami tej tradycji, trzeba je rozpatrzyć w szerszym kontekście; nie tylko księgi Rodzaju, ale całego Starego a nawet i Nowego Testamentu. Należy innymi słowy sprawdzić, jakie miejsce zajmują w całości objawienia Bożego.

W świetle tych zasad istotnymi składnikami wspólnymi obydwu do-kumentom w pierwszych trzech rozdziałach, a przez to nauką objawioną, zamierzoną przez autora natchnionego są: 1) dobroć Boga dla człowieka; 2) wyższość człowieka nad przyrodą i obowiązek pracy od początku jego istnienia; 3) dobroć etyczna, tj. faktyczna bezgrzeszność człowieka na początku; 4) pochodzenie małżeństwa od Boga; 5) pogorszenie etycznego stanu człowieka z jego własnej winy. 
Natomiast wolność od zagrożenia przez śmierć jest składnikiem treściowym tylko jednego dokumentu, w zakresie którego jest szczegółem będącym poza właściwym zamysłem autora dokumentu, zatem tym bardziej nie jest zamysłem autora księgi Rodzaju. Po wtóre nie jest potrzebna do osiągnięcia celu opisu pradziejów, który chce być etiologią pod postacią historii, albowiem dla przyczynowego tłumaczenia śmierci wystarczy przyjąć, że nasza śmierć, obecnie, po upadku, jest karą za grzech. Wniosek może być tylko następujący: W świetle kontekstu, którym jest opis pradziejów ludzkości, jest naukowo omylnie pewne a epistemologicznie prawdopodobne - że wolność człowieka przed upadkiem od zagrożenia przez śmierć nie jest nauką, którą autor Genesis chciał przekazać czytelnikom, czyli nie jest przez te rozdziały Pisma św. objawiona ${ }^{11}$.

Pozostaje etap trzeci i pytanie: Czy późniejszy rozwój Objawienia i wyjaśnienie znaczenia Pisma św. przez Magisterium każą uznać warunkową nieśmiertelność przed upadkiem za naukę: a) istotnie przez Pismo św. objawioną; b) i to objawioną już w II. i III. rozdziale księgi Rodzaju. Nauką innych ksiąg Pisma św. zajmą się dalsze ustępy referatu.

Analiza dokumentów nauczania kościelnego wykazała, że tylko Pawłowe Crcdo przypisuje człowiekowi przed upadkiem warunkową nieśmiertelność i że to przypisanie ma tylko cechy nauki bezpiecznej dla wiary, a teologicznie prawdopodobnej. Znaczy to, że w tym miejscu Pawłowe Credo nie wyjaśnia, jakie jest właściwe znaczenie Pisma św., ale ogranicza się do wskazania, która interpretacja jest dla wiary bezpieczna, czyli nie grozi zaprzeczeniem prawdy objawionej. Poza tym potrzebuje właśnie w tym punkcie uzasadnienia, dlatego że jest omylne i nie zabezpieczone w tym miejscu przed błędem przez Ducha Św. Ponieważ dotychczasowe rozważania wykazały, że nie ma go w innych dokumentach urzędu nauczycielskiego, musi być uzasadnione przez Pismo św. Zatem samo przez się nie może być w tym zagadnieniu wystarczającą podstawą do ustalenia właściwego znaczenia Pisma św.

Wobec takiego stanu kościelnej nauki o darze warunkowej nieśmiertelności przed upadkiem, analiza całości objawienia Starego i Nowego Testamentu w sprawie śmierci i nieśmiertelności człowieka pozostaje jako jedyna droga do odpowiedzi na pytanie, czy dar warunkowej nieśmiertelności jest treścią istotnie przez Boga Objawioną.

11 Ten wniosek nabiera jeszcze większej pewności, jeśli się przyjmie pogląd biblistów, że Kodeks Kapłański był interpretacją, kilkaset lat młodszą, Dokumentu Jahwistycznego i pominął wszystko, co w nim uznał za nieistotne dla religijnej tradycji Izraela. Wolność od zagrożenia przez śmierć została więc uznana za nieistotną dla religii Mojżeszowej jeszcze przed powstaniem księgi Rodzaju. 


\section{BIBLIJNE POJĘCIE ŚMIERCI W STARYM TESTAMENCIE}

Rozpoczynając rozważania nad nauką jahwistycznego opowiadania o upadku człowieka i jego następstwach w świetle całości objawienia Starego i Nowego Testamentu pytamy: Co z jahwistycznego opowiadania zostało przejęte, a co nie zostało przejęte jako nauka istotnie objawiona w późniejszym rozwoju objawienia? Jakie nowe treści późniejszy rozwój objawienia dodał do religijnej nauki Jahwisty? Ten trzeci stopień egzegetycznego studium będzie spełnieniem zalecenia soborowej Konstytucji Dei Verbum, które każe wykładać Biblię w kontekście całej nauki Pisma św. oraz Tradycji w imię tego, że „Pismo św. należy czytać i wykładać w tym samym Duchu, w którym zostało napisane" $(3,12)$.

Rozważania pierwszego i drugiego etapu egzegetycznego doprowádziły do wniosku, że wolność człowieka przed upadkiem od zagrożenia przez śmierć nie jest nauką objawioną, którą autor natchniony Rdz. zamierzał przekazac czytelnikom. Jedną z podstaw tego wniosku było to, że do wolności od zagrożenia przez śmierć dochodzimy tylko drogą wnioskowania $z$ popularnego i obrazowego opowiadania Jahwisty. Aby zaś jakikolwiek wniosek był istotnie objawiony, musi z koniecznością wynikać z przesłanek istotnie objawionych. A wolność człowieka przed upadkiem od zagrożenia przez śmierć tylko wtedy może w sposób konieczny wynikać z opowiadania Jahwisty, jeśli: a) pojęcie śmierci jest w nim ściśle określone; oraz b) posiada taką samą treść jak w tradycyjnej nauce katolickiej o warunkowej nieśmiertelności. Jeśli natomiast pojęcie śmierci miałoby u Jahwisty i w Biblii inną treść, również i wolność od śmierci, czyli nieśmiertelność będzie miała w Biblii z koniecznością inną treść, niż warunkowa nieśmiertelność cielesna w tradycyjnej teologii. W takim zaś wypadku warunkowa nieśmiertelność cielesna nie będzie miała znamion nauki istotnie objawionej. Biblijne pojęcie śmierci posiada zatem kluczowe znaczenie dla rozwiązania postawionych wyżej pytań.

Otóż, pojęcie śmierci u Jahwisty zawiera wprawdzic składnik ontologiczny, stanowiący definicję śmierci w teologii katolickiej, ale tym różni się od niej, że nie jest ani formalne ani naturalistyczne, lecz przede wszystkim religijne. Zawiera aspekt ontologiczny, bo Jahwista uważa śmierć za koniec egzystencji człowieka na ziemi: „Wrócisz do ziemi, z której zostałeś wzięty; bo prochem jesteś i w proch się obrócisz" (Rodz. 3, 19) — tak brzmiał wyrok Boga na upadłych ludzi. Tenże sam wyrok odsłania znamienną ảwoistość w pojmowaniu śmierci przez Jahwistę: z jednej strony ma ona podstawę w cielesnej naturze człowieka, a z drugiej Bóg jest jej właściwą przyczyną i z jego się ona woli wywodzi. Widać tę dwoistość wyraźnie w jahwistycznym rozdz. $6 \mathrm{Rdz}$ : ,Wtedy Jahwe rzekł: «Nie może 
pozostać duch mój w człowieku zawsze, gdyż człowiek jest istotą cielesną; niechaj więc żyje tylko sto dwadzieścia lat»" (6, 3). Dzięki temu powiązaniu śmierci z wolą Bożą jej pojęcie u Jahwisty nie jest naturalistyczne, ale przede wszystkim religijne.

Religia Izraela nie tylko bardzo długo nie posiadała obowiązującego pojęcia śmierci i życia pozagrobowego, ale aż do czasu księgi Mądrości była bez jasno określonego poglądu na życie pozagrobowe. Wypracowywała je $z$ trudem i powoli. Ponieważ myślało nad nim wielu autorów, w różnych czasach i w różnych środowiskach kulturalnych, nie można oczekiwać, by jego treść była dokładnie taka sama we wszystkich księgach Starego Testamentu. Ale kierunek rozwojowy tego pojęcia jest w nich widoczny wyraźnie. Mianowicie, z uplywem lat religijne treści tego pojęcia stają się nie tylko jaśniejsze i bogatsze, ale i coraz ważniejsze; a składnik ontologiczny staje się coraz bardziej drugorzędny, tak że ostatecznie - w księdze Mądrości - pojęcie śmierci składa się wyłącznie z treści religijnych.

Widoczna u Jahwisty dwoistość w pojmowaniu śmierci, objawiająca się tym, że śmierć jest $z$ jednej strony następstwem cielesnej natury człowieka, a z drugiej pochodzi z wyroku woli Bożej, nasuwa wątpliwość, czy można $z$ opowiadania o upadku wydedukować cielesną nieśmiertelność przed upadkiem. Albowiem stosunek ontologicznego i religijnego składnika $\mathrm{w}$ tym pojęciu nie jest dokładnie określony; tym samym również nie jest dokładnie określona treść pojęcia. A z pojęcia o niedokładnie określonej treści nie można wnioskować niczego określonego.

Tę dwoistość w pojęciu śmierci odnajdujemy także w innych ksiẹgach Starego Testamentu; np. w Ps 90, 3: „Do prochu każesz wracać śmiertelnym", który nawiązuje do Rodz 3, 19. Ale w wielu wypowiedziach to powiązanie śmierci $z$ jej naturalnym źródłem znika zupełnie tak, że śmierć bywa określona wyłącznie przez stosunek umarłego do Boga: pojęcie śmierci jest wówczas czysto religijne.

Smierć nie staje naprzeciw człowieka jako jego nieprzyjaciółka, ale jest aktem B og a, który odbiera to samo życie, jakie sam dał. Juz I Sm 2,6 - przed niewolą babilońską - oświadcza: „Jahwe da.je śmierć i życie, w grób wtrąca i zeń wyprowadza". Podobnie wyraża się Put 32 , 39: „Poza mną nie ma żadnego Boga. Ja zabijam i ja ożywiam. Ja raniẹ i ja sam uzdrawiam". Współczesny księdze Joba Ps 88,7 wypowiada tę samą myśl. Bóg zaś, który zsyła śmierć, sam ją również oddala, np. na prośbę króla Ezechiela, 4 Krl 20, 11.

Przez śmierć człowiek przestaje istnieć; ale nie w tym znaczeniu, jakby śmierć była całkowicie i pod każdym względem końcem egzystencji, tj. jej unicestwieniem. Umarły bowiem ,schodzi w Szeol” (Jり 
7, 9), w otchłań, gdzie jego udziałem jest pomniejszone i pozbawione szczęścia bytowanie cienia w wiekuistym śnie. Aż do niewoli babilońskiej wyobrażano sobie bowiem, że w szeolu, otchłani jednakowo mizerne życie pędzą cienie ludzi dobrych i złych. Właśnie dlatego szeol wydobywa na jaw religijną istotę śmierci, którą jest oddalenie od Boga. Być umarłym znaczyło bowiem dla Biblii Starego Testamentu tyle, co być z dala od B o ga, czyli z dala od Jego dobrotliwej opieki. Obszerny zestaw różnych form tego oddalenia od Boga przez śmierć daje Ps 88, który być może - pochodzi sprzed niewoli babilońskiej. Umarli nie doznają tych dowodów opieki, jaką Bóg otacza na ziemi swój naród wybrany a ich brak nazywa Psalmista zapomnieniem przez Boga: „Między zmarłymi - pisze - jest moje posłanie... o których już nie pamiętasz, którzy wypadli z Twojej opieki” (88,6). Stawia również retoryczne pytanie: „Czy dla umarłych czynisz cuda?... Twoje cuda się ukazują w ciemnościach, a dobroczynność Twoja w ziemi zapomnienia?" (Ps 88, 11-12).

Po drugie być umarłym znaczyło również tyle, co być wyłączonym od oddawania Bogu czci i od rozgłaszania Jego dobrodziejstw. Księgi Starego Testamentu wskazują w związku ze śmiercią najczęściej na to właśnie wyłączenie od czci Bożej, co uprawnia do wniosku, że w nim widzą najważniejszy rys śmierci w jej religijnym aspekcie. Tak czynią: Ps 6,$6 ; 30,10 ; 88,11 ; 111$, 4; 145, 7; Iz 38, 18. Np. Ps 6, 6 mówi: „Nikt z umarłych nie wspomni o Tobie: w krainie zmarłych któż Cię wychwala?". A u Iz 38, 18 czytamy: „Zaiste nie Szeol Cię sławi, ani śmierć wychwala Ciebie”. I śmierć i szeol zostały w tym tekście uosobione. A G. von Rad - w dziele Th e olog i e des Alten Testaments ${ }^{12}$ — uważa oddalenie od Boga i odsunię. cie od oddawania czci Bogu za wyczerpującą definicję teologiczną śmierci w Starym Testamencie.

Autorzy, którzy mieli tak zasadniczo religijne pojęcie śmierci, musieli widzieć szczególnie ścisły związek między śmiercią - tak pojętą a grzechem. Rzeczywiście, od dawna i często głosili, że sprawiedliwość powoduje życie, a grzech śmierć na tej zasadzie, że Bóg wygubi grzeszników, a sprawiedliwych obdarzy długim i szczęśliwym życiem. Smierć, będąca karą za grzech, nie oznaczała u nich pozagrobowej kary, ale jedynie przedwczesny koniec nieszczęśliwego życia na ziemi. Już w I połowie VIII wieku przed Chr. wypowiadał tę myśl prorok Amos: „Szukajcie dobra, a nie zła, abyście żyli" (Am 5, 14). Kilkakrotnie powtórzyła ją księga Przysłów; np. rozdz. 10, 24-25: „Zło, którego się boi, spadnie na grzesznika; sprawiedliwy uzyska to, czego pragnie. Gdy wicher zawieje,

12 München 1968, t. II, 371. 
nie ma grzesznika, lecz sprawiedliwego podstawy są wieczne”. Podczas niewoli babilońskiej przypomniał ją Ezechiel: ,Umrze tylko ta osoba, która zgrzeszy” (18, 20). „Jeśli sprawiedliwy odstąpił od sprawiedliwości, dopuścił się grzechu i umarł, to umarł z powodu grzechów, które popełnił” $(18,26)$. Po niewoli odnajdujemy ją w Psalmach. Np Ps 37, 18-20 powiada: „Pan ma staranie o życie prawych, a ich dziedzictwo trwać będzie na wieki... Niezbożni natomiast poginą, wrogowie Pana jak krasa łąk zwiędną".

Budująca księga Syracha, pochodząca z I ćwierci II wieku przed Chr., wielokrotnie w swych przestrogach przypomina, że śmierć - przedwczesna i w nieszczęściu — jest karą za grzech osobisty, zesłaną przez Boga, który każdemu odpłaca według uczynków; podobnie jak życie — długie i szczęśliwe - jest nagrodą za dobro etyczne; 5, 6-7; 9, 9; 16, 6-11; 21,$10 ; 35,19-22 ; 40,14$. Do tego, dość rozpowszechnionego poglądu, dodaje drugie powiązanie naszej śmierci z grzechem, mianowicie z grzechem Ewy. Powiada bowiem, że śmierć wszystkich nas - tak dobrych jak złych - jest następstwem grzechu Ewy. „Początek grzechu przez kobietę - pisze - i przez nią też wszyscy umieramy" (25, 24). Z całego jahwistycznego opowiadania o stworzeniu i upadku człowieka wspomina tylko grzech rajski Ewy, a z jego następstw - tylko powszechną śmiertelność. Nie mówi nic o nieśmiertelności warunkowej przed upadkiem, ale powstaje pytanie, czy nie jest ona równoważnie zawarta w treści jego wypowiedzi. Z tym zaś pytaniem jest związane drugie, bardziej zasadnicze: Co właściwie zamierzał autor natchniony wyrazić, gdy w roz-. dziale 25 przypominał grzech Ewy?

Przytoczony, 24 wiersz jest częścią kontekstu, w którym autor natchniony przestrzega czytelnika przed złą kobietą żoną opisując, ile nieszczęść ze sobą wnosi; z kolei przeciwstawia jej dobrą kobietę i opisuje, ile różnorakiego dobra ze sobą wnosi. Jedno i drugie ilustruje przykładami zaczerpniętymi z literatury Starego Testamentu, przede wszystkim zaś literatury mądrościowej. Zamysł jego jest dydaktyczny: odwodzić od zła, zachęcić do dobra - a nie religijno-dogmatyczny: uczyć prawd wiary. Zatem nie było zamysłem autora uczyć w rozdz. 25, 24, że jeden historyczny grzech jednej kobiety rzeczywiście spowodowal śmierć nas wszystkich. Przez ten odnośnik do Rodz. zamierzał jedynie uplastycznic i wzmocnić swe przestrogi przed złą kobietą. Ponieważ zaś objawione przez Boga w Piśmie Sw. jest to, co jest właściwym przedmiotem zamysłu autora natchnionego, nie ma w Syr 25, 24 żadnej podstawy do tego, by twierdzić, że przez 25, 24 zostało nam istotnie objawione twierdzenie, iż grzech rajski - i to konkretnie grzech kobiety Ewy - jest historyczną przyczyną naszej, aktualnej i powszechnej śmierci. 
Należy dodać, że nawet gdyby wiersz 24 wyrażał właściwy zamysł autora natchnionego, to jego twierdzenie byłoby wprawdzie istotnie objawione, ale tylko w tym znaczeniu, w jakim je rozumiał autor. Odnosiłoby się zatem do naszej śmierci, ale rozumianej w tym samym religijnym znaczeniu nieformalnym, jakie do niej przywiązywał Syrach. Przy takim znaczeniu śmierci nie można zaś wnioskować o posiadaniu warunkowej nieśmiertelności cielesnej przed upadkiem, albowiem księga Mądrości dostarcza oczywistego dowodu na to, że zaprzeczenie śmierci, czyli nieśmiertelność, czysto religijnie pojęte nie tylko nie wyklucza śmierci pojętej ontologicznie i formalnie, ale wprost ją zakłada.

Historia religii i objawienia Starego Testamentu dowodzi jednak, że przedstawiona wyżej nauka o śmierci jako karze za grzech osobisty nie była - w III wieku przed Chr. - ani ostatecznym i obowiązującym określeniem stosunku między grzechem a śmiercią, ani wyrazem nauki objawienia. Z tego bowiem okresu pochodzi najprawdopodobniej księga Eklezjastesa-Qoheleta, która wyłamuje się z dobrze widocznej linii rozwojowej poglądów Izraela na śmierć. Albowiem Q ohelet nie widzi w naszej śmierci kary za grzech, ale konieczność naturalną, wspólną człowiekowi i zwierzęciu. Oświadcza bowiem: „Los synów ludzkich jest ten sam, co i los zwierząt;... jaka śmierć jednego, taka śmierć drugiego i oddech życia, nephesz, ten sam" $(3,19)$. A przyczyną śmierci jest to, że ,powstało wszystko z prochu i do prochu wszystko znów wraca" (3, 20). W jego księdze nie ma żadnej z tych cech, które złożyły się na religijne pojęcie śmierci w Starym Testamencie, mające wówczas już kilka wieków istnienia za sobą; ani związku z grzechem; ani oddalenia od Boga; ani wykluczenia od czci Bożej; ani sprawczego postanowienia Bożego.

Ale Q o helet jest księgą natchnioną przez Boga; na równi z pozostałymi księgami Starego i Nowego Testamentu. A nieskończenie mądry Bóg nie może popaść w sprzeczność sam ze sobą. Skoro więc w poglądach na śmierć jest widoczna sprzeczność między Qoheletem a innymi księgami Starego Testamentu, wniosek może być tylko jeden: religijne pojęcie śmierci, przedstawione wyżej nie osiągnęło wówczas jeszcze poziomu nauki istotnie przez Boga objawionej. Było jedynie przygotowaniem do niej, wymagającym dalszych uściśleń i sprostowań.

Kryło bowiem w sobie dwa braki. Zasadniczym jego niedostatkiem był brak nauki o pośmiertnej nagrodzie i karze. A przypisanie jednako.. wego losu w szeolu wszystkim zmarłym - tak dobrym jak złym - nie mogło się ostać przed krytyką, prowadzoną nie tylko w imię sprawiedliwości Bożej, ale także w imię dobroci Boga objawiającego się w historii Izraela. Natomiast fakty codziennego i powszechnego doświadczenia odsłaniały drugi brak; sprawiały bowiem, że była nie do utrzymania rozpowszechniona interpretacja zasady ,pobożność powoduje życie, a grzech 
jest przyczyną śmierci”. Niejeden bowiem sprawiedliwy żył krótko, w nędzy i ucisku, a niejeden bezbożny długo, w dostatku i szczęściu.

Ale to samo starotestamentalne pojęcie śmierci — właśnie dlatego, że widziało w niej wydarzenie religijne, a nie zjawisko naturalne i biologiczne - kryło w sobie możliwości przezwyciężenia nie tylko dwu wspomnianych trudności, ale nawet samej śmierci. Reczywiście, już S t ary Testament wskazał dwa sposoby przezwyciężnia śmierci: a) przez naukę o zmartwychwstaniu do życia szczęśliwego; b) przez zmianę w pojęciu śmierci, polegającą na usunięciu z niego wszystkich treści przyrodzonych, tak biologicznych jak ontologicznych, czyli na ograniczeniu go do samych treści religijnych. Ta zmiana umożliwiła bowiem wprowadzenie do religii Starego Testamentu nauki o pośmiertnej nagrodzie u Boga dla sprawiedliwych i o pośmiertnej karze dla bezbożnych. Tego przełomowego kroku - przygotowanego przez Psalmy 16,$10 ; 49,16 ; 73,20$ - dokonała na przełomie II i I wieku przed Chr. księga Mądrości.

\section{SMIERĆ I NIESMIERTELNOŚC W KSIĘDZE MĄDROŚCI}

Obok mądrości Syracha jest ona drugą księgą Starego Testamentu, która - milcząc ale niedwuznacznie - nawiązuje do jahwistycznego opowiadania o stworzeniu i upadku człowieka. Czyni to dwukrotnie: 1, 1314 oraz $2,23-24$.

W 1, 13-14 czytamy: „Bóg śmierci nie uczynił i nie cieszy się ze zguby żyjących. Stworzył bowiem wszystko po to, by było i zdrowie niosą byty tego świata: nie ma w nich śmiercionośnego jadu ani władania Otchłani na tej ziemi”. Uosobiona Otchłań, a i d e s, w ostatnim pół. wierszu jest greckim odpowiednikiem hebrajskiego szeolu. Osnowa 2, 23-24 jest zaś następująca: „Dla nieśmiertelności Bóg stworzył człowieka - uczynił go obrazem swej własnej wieczności. A śmierć weszła na świat przez zawiść diabła i doświadczą jej ci, którzy doń należą”.

Treść księgi wypełniają zachęty do szukania i zdobywania mądrości oraz przestrogi przed życiem bezbożnym. Jedne i drugie wyrastają zaś z następującego założenia: Śmierć nie jest nieuniknioną koniecznością, ale człowiek sam dobrowolnie na siebie ją ściąga przez swe złe życie. To zaś założenie znajduje w księdze podwójne uzasadnienie: 1) Z woli Boga umierać nie jest przeznaczeniem człowieka; 2) Sprawiedliwość ze swej natury pociąga za sobą nieśmiertelność — ,sprawiedliwość nie podlega śmierci” (1, 15) — a grzeszne życie mocą swej natury zasługuje na śmierć. Stąd powstaje zasadnicze pytanie, o jakiej śmierci i o jakiej nieśmiertelności autor natchniony pisze?

Zna i stosuje on w toku swych wywodów ontologiczne i formalne po- 
jęcie śmierci, rozumianej jako koniec egzystencji człowieka na ziemi. Owszem, tak pojętą śmierć uważa za naturalną, za związaną z istotą człowieczeństwa: nazywa bowiem wszystkich ludzi śmiertelnikami, thnetoi. Ale w obydwu miejscach nawiązujących do Rdz. posługuje się zupełnie innym, czysto religijnym oraz czysto teologicznym pojęciem śmierci; jest ono dlatego czysto religijne i zarazem czysto teologiczne, że określa śmierć wyłącznie przez stosunek do Boga, przedmiotu zarówno religii jak teologii. Smierć, o której tam pisze jest niecielesna.

Albowiem cielesna, naturalna i ontologiczna śmierć sprawiedliwych ani nie jest tą śmiercią, o którą autorowi chodzi, ani nie należy - jako część składowa - do jej pojęcia. Wszak cielesna śmierć sprawiedliwych tylko przez głupich może być uważana za śmierć: „Zdało się oczom głupich, że pomarli" $(3,2)$; tylko głupi mogą w niej widzieć unicestwienie $(3,3)$, stanowiące istotną cechę śmierci. Tylko w ludzkim rozumieniu jest ona kaźnią $(3,4)$; natomiast w rzeczywistości jest objawem ogólnej opieki Boga, który tą drogą ich nawiedza $(3,7)$ oraz doświadcza jak złoto w tyglu, po to, by ich znaleźć godnymi siebie $(3,5-6)$, tj. godnymi trwania na stałe przy Bogu i w miłości Boga do nich $(3,9)$. Cielesna śmierć sprawiedliwych nie pociąga zatem wcale oddalenia od Boga, które w starszych księgach Starego Testamentu stanowiło teologiczną i religijną istotę śmierci. A śmierć cielesna, naturalna i ontologiczna dlatego nie wchodzi w skład pojęcia tej śmierci, o której księga Mądrości zasadniczo rozprawia, że nie jest koniecznym następstwem cielesnej natury człowieka, ale bezbożni — i tylko bezbożni — sami osobiście ,ściągają ją na siebie słowem i czynem... i zawierają z nią przymierze" $(1,16)$.

Ta śmierć do tego stopnia nie jest cielesną, naturalną i ontologiczną, że nawet nieśmiertelność, czyli wolność od tej śmierci zakłada przejście przez śmierć cielesną: albowiem nie jest udziałem ludzi żyjących na ziemi, ale tylko dusz ludzi sprawiedliwych, które są w ręku Boga $(3,1)$.

Ta nie cielesna, ale czysto religijna śmierć, spadająca tylko na bezbożnych, po śmierci cielesnej, ma w powiększeniu ujemne cechy starotestamentalnego szeolu, otchłani. Albowiem Bóg na głowę strąci bezbożnych, oniemiałych z powodu tego co ich spotyka $(4,19)$; użycie obrazowego wyrażenia ,strąci $n_{t}$, wskazuje na szeol, otchłań, jako na miejsce skierowania dusz $i \quad z b o z ̇ n y c h$ Ta śmierć - w szeolu jest zagubą $(1,12)$, olethros, tak dogłębną, że z życia ludzkiego właściwie nic nie zostanie, co by zasługiwało na nazwę życia: ,wstrząśnie nimi od podstaw i zostaną doszczętnie zniszczeni" $(4,19)$. Nie jest to jednak całkowite unicestwienie, ale bytowanie w udręczeniu, odyne $(4,19)$. 
Natomiast religijna, niecielesna nieśmiertelność polega na tym, że dusze sprawiedliwych mają zapłatę, mistos, w Bogu $(5,15)$, w którego bliskości i miłości będą na zawsze trwały $(3,9)$. One ,będą sądzić ludy, zapanują nad narodami” (3, 8), „dostąpią dóbr wielkich” $(3,5)$, będą triumfować W wieczności uwieńczone $(4,2)$, a równocześnie „Pan królować będzie nad nimi na wieki" $(3,8)$. Będą nawet policzone między synów Bożych $(5,5)$. Ich losem jest więc wiekuiste przebywanie z Bogiem, a bliskość Boga przekreśla zasadniczą cechę religijnego pojęcia śmierci w Starym Testamencie, mianowicie oddalenie od Boga. Z tego powodu autor księgi Mądrości nie zdradził starotestamentalnego pojęcia religijnego śmierci, ale wyciągnął z niego logiczny wniosek, gdy stanu dusz sprawiedliwych po cielesnej śmierci nie uważał za religijną śmierć, ale za nieśmiertelne życie. Jego poglądy stanowią szczytowy punkt $\mathrm{w}$ rozwoju religijnego pojęcia śmierci w Biblii.

Księga Mądrości przejęła, rozwinęła i przetworzyła również tradycyjną naukę o śmierci jako następstwie grzechu, wyrażając ją w dwu nowych pojęciach: kary oraz czysto religijnie pojętej śmierci. Bezbożność, niegodziwość - dowiadujemy się - do tego stopnia domaga się kary, epitimõsis, katadike (12, 26-27), że nie tylko Bóg, ale i przyroda ,sroży się jako kara, eı kolasin, przeciw niegodziwym $(16,24)$, a ostateczną karą, to terma tes katadikos, jest przyspieszona, nieszczęśliwa śmierć onotologicznie pojęta $(12,27 ; 19,5)$. Ale swoje zachęty do starań o prawdziwą Mądrość oraz do zbożnego życia podbudowuje zasadę światopoglądową: „zapłatą, misthos, za zbożne życie jest nieśmiertelność, a karą za bezbożność jest śmierć". Zarówno śmierć jak nieśmiertelność mają w niej nowe, czysto religijne znaczenie, wyżej omówione. Podstawy do tego powiązania między bezbożnym życiem a teologiczną śmiercią oraz między sprawiedliwością wobec Boga a teologiczną nieśmiertelnością nie szuka autor $\mathrm{w}$ pierworodnym upadku, ale widzi ją w wymaganiach moralnego $ł$ adu i sprawiedliwości. Powiada bowiem, że ze swej natury „,sprawiedliwość nie podlega śmierci” $(1,15)$; że „,w zażyłości z Mądrością leży nieśmiertelność" $(8,17)$; że sprawiedliwi są godni wiecznego życia u Boga $(3,5 ; 4,2)$, które jest zapłatą za ich zbożne życie $(5,15)$. Natomiast bezbożni są warci śmierci $(1,16)$, którą ściągają na siebie słowem i czynem; a ta śmierć jest karą; taką, jakiej wymaga ich bezbożność $(3,10)$. Właśnie sprawiedliwość będąca istotnym składnikiem ładu moralnego, domaga się, by należna zapłata została wypłacona; ona również wymaga, by kara była sprawiedliwa: kara niesprawiedliwa nie jest, karą, ale nieludzką zemstą. Dlatego sprawiedliwość należy tak do pojęcia zapłaty jak do kary. 
$\mathrm{Na}$ tym tle staje się jaśniejsza myśl obydwu przytoczonych wyżej ustępów - z rozdz. 1, 13-14 oraz 2, 23-24 - które nawiązują do jahwistycznego opowiadania o pierworodnym upadku. W rozdz. 1, 12 kieruje autor do bezbożnych wezwanie: „Nie gotujcie sobie zguby własnymi rękami", czyli samochcąc. W następnych wierszach podbudowuje to wezwanie podwójnym uzasadnieniem: negatywnym w w. 13, a pozytywnym w w. 14. W wierszu 13 mówi: „Bo śmierci Bóg nie uczynił”. Jakiej śmierci? Tej, przed którą zabezpiecza sprawiedliwość (1, 15), a którą „,bezbożni ściągają na siebie słowem i czynem” (1-16). Tą śmiercią, której Bóg nie uczynił, nie jest zatem naturalna śmierć ontologiczna, która jest jednakowo nieuniknioną koniecznością dla wszystkich ludzi, tak dobrych jak złych. Ponieważ spotyka tylko bezbożnych, jest to śmierć pojęta czysto religijnie. Uzasadnienie pozytywne, podane w wierszu 14, wyprowadza przeznaczenie człowieka z celu stworzenia: „Stworzył bowiem wszystko panta, po to, aby było"; to znaczy po to, aby bytowało i żyło w taki sposób, jaki jest odpowiedni naturze każdego gatunku, genesis $(1,14)$. W zastosowaniu do człowieka, znaczy to, że Bóg stworzył go do życia prawdziwie ludzkiego. Tymczasem przebywanie w szeolu, jak wyjaśniono wyżej, nie zasługuje w ogóle na nazwę życia: jest bytowaniem w stanie śmierci. Skoro więc Bóg stworzył człowieka do prawdziwego życia, nie ma w jego naturze „śmiercionośnego jadu” (1, 15) tak, by człowiek musiał umrzeć śmiercią w szeolu. Tę zaś śmierć ściągają na siebie dobrowolnie „słowem i czynem” $(1,16)$ bezbożni; natomiast „sprawiedliwość nie podlega śmierci” w szeolu $(1,15)$.

Drugie podbudowanie zachęt do szukania mądrości i świętości w rozdz. 2, 23-24 - nawiązuje do obydwu dokumentów Rdz., składających się na opis pradziejów: mianowicie do opisu stworzenia człowieka na obraz Boga z Kodeksu Kapłańskiego oraz do historii upadku z Dokumentu Jahwistycznego. A przeznaczenie człowieka do nieśmiertelności nie tylko wyraźnie głosi, ale je ponadto głęboko teologicznie uzasadnia. „Dla nieśmiertelności, ep aftharsia (i) - pisze - Bóg stworzył człowieka" (2, 23). Bezpośredni kontekst — rozdz. 2, 22-23 oraz rozdz. 3, 1-9dowodzi ponad wszelką wątpliwość, że jest to nieśmiertelność dostępna tylko dla sprawiedliwych i świętych, od której wykluczeni są źli i bezbożni. Jest to zatem nieśmiertelność pojęta czysto religijnie i polega na pośmiertnej nagrodzie w Bogu. Podstawę przeznaczenia do tak pojętej nieśmiertelności widzi autor w stworzeniu człowieka na obraz Boga ,nieśmiertelnego i wiekuistego”. Pisze bowiem: „Uczynił go obrazem swej własnej wieczności" (2, 23). Zatem w zamysłach Bożych śmierć nie jest przeznaczeniem człowieka. Jaka śmierć? Ta, która jest zaprzeczeniem nieśmiertelności czysto religijnie pojętej, o której mowa w 2, 23, czyli śmierć pojęta czysto religijnie. Kiedy więc w następnym wierszu czy- 
tamy ,'śmierć weszła na świat przez zawiść diabła” (2, 24), nie może ulegać najmniejszej wątpliwości, że jest tu mowa tylko o śmierci pojętej czysto religijnie, a nie o naturalnej śmierci ontologicznej, która jest nieuniknioną koniecznością wszystkich ludzi, tak dobrych jak złych. Jest to tym pewniejsze, że w drugiej części wiersza 24 autor wyjaśnia, że tej śmierci doświadczają ci ludzie, którzy należą do diabła; którzy są jego własnością przez to, że ulegli pokusie jak Adam i Ewa: ,doświadczą jej ci, którzy do niego należą".

Po wszystkim, co wyżej powiedziano, można obecnie przystąpić do odpowiedzi na zasadnicze pytanie: Jakie treści dotyczące pierwotnej historii ludzkości, Mdr przejęła od Rdz? Otóż przejęła - po pierwsze - tezę: Człowiek został stworzony przez Boga jako moralnie prawy, czyli nie tylko wolny od grzechu, ale dobry i sprawiedliwy. Wprawdzie autor nie wypowiada wyraźnie tego twierdzenia, ale wynika ono w sposób konieczny z obydwu miejsc nawiązujących do Rdz, czyli jest $\mathrm{w}$ nich zawarte równoważnie, formaliter implicite. Jeśli bowiem śmierć nie pochodzi od Boga, a śmierć ponoszą tylko grzesznicy, to w świetle 1, 13-14 — Bóg stworzył człowieka bez grzechu. Jeśli — po wtóre - stwarzając przeznaczył go do nieśmiertelności, a nieśmiertelność zdobywają tylko sprawiedliwi, to — w myśl 2, 23 - Bóg stworzył człowieka sprawiedliwym. Mdr stanowi zatem ważny krok w rozwoju objawionej nauki o stanie sprawiedliwości pierwotnej, czego dotychczas nie zauważono.

Tę, przejętą od Rdz, treść Mdr wzbogaciła własną w y jaśniającą interpretacją: Bóg stwarzając człowieka, przcznaczyl go dowiekuistego szczęścia w Bogu.

Po drugie przejęła również na k ę:

Grzech nie pochodzi od Boga, ale odpowiedzialność za niego ponosi człowiek przez swą wolną wolę.

Nie przejęła natomiast nauki o warunkowej nieśmiertelności cielesnej przed upadkiem: co nie ulega żadnej wątpliwości. Albowiem w obydwu miejscach, które nawiązują do Rdz i mówią o śmierci i nieśmiertelności, nie chodzi o cielesną śmierć i cielesną nieśmiertelność, ale o śmierć niecielesną oraz o nieśmiertelność niecielesną czysto religijnie pojętą. Mdr mówi więc w tych miejscach o śmierci i nieśmiertelności w zupełnie innym znaczeniu niż tradycyjna interpretacja teologiczna Dokumentu Jahwistycznego.

Nigdy - z kolei - Mdr nie uzasadnia naszej śmierci cielesnej grzechem Adama i Ewy. Przecież, jeśli człowiek stworzony przez Boga posiadał na początku warunkową nieśmiertelność cielesną, upadek pierworodny jest prawdziwie przyczyną cielesnej śmierci każdego z nas. Gayby 
więc Mdr przyjęła naukę o warunkowej nieśmiertelności cielesnej przed upadkiem, nie mogłaby nie wskazać na grzech pierworodny jako przyczynę naszej cielesnej śmierci.

Wreszcie zasada ,śmierć jest karą za grzech", która w Mdr występuje wielokrotnie, nie została wyprowadzona $\mathrm{z} \mathrm{Rdz}$, ale jest przedstawiona jako wymaganie ładu moralnego czyli sprawiedliwości. Po wtóre odnosi się przede wszystkim do religijnie pojętej śmierci; tylko niekiedy - do przyspieszonej i nieszczęśliwej śmierci cielesnej; nigdy zaś - do śmierci cielesnej rozumianej po prostu i bez tego zacieśnienia.

\section{GRZECH ADAMA I SMIERC W LISTACH SW. PAWEA}

Sw. Paweł dwukrotnie nawiązuje w swych listach do jahwistycznego opowiadania o pierworodnym upadku: bardzo zwięźle w 1 Kor 15, 21 oraz szeroko w słynnym rozdziale szóstym Rz. Jako były uczeń i zwolennik sekty faryzeuszów, a naówczas bohaterski wyznawca i apostoł Chrystusa, wykładał w nich Dobrą Nowinę, która dawała wierzącym podwójną możliwość przezwyciężenia śmierci cielesnej. Naprzód zaraz po tej śmierci i pomimo niej: przez przebywanie duszy razem z Chrystusem, które nie jest stanem śmierci, ale życiem doskonałym < 1 Kor $13,10\rangle$ do tego stopnia, że Paweł oczekuje z utęsknieniem jego nadejścia. Pisze o tym: „Pragnę odejść i być z Chrystusem, bo to bardzo wiele lepsze" $\langle$ Flp 1, 23 $\rangle$. Drugim sposobem będzie powszechne zmartwychwstanie cielesne w dniu powtórnego i chwalebnego przyjścia Chrystusa, przez które śmierć zostanie ostatecznie zwyciężona $\langle 1$ Kor 15, 5458 ). Ponieważ zaś cielesne zmartwychwstanie jest koniecznym warunkiem ostatecznego przezwyciężenia śmierci, wynika stąd, że u św. P awla pojęcie śmierci nie ogranicza się do jej religijnych, teologicznych aspektów, ale obejmuje również stronę cielesną; nie jest zatem czysto religijne - jak w Mdr - ale całości owe.

Oczywiście wie on dobrze, iż cielesna śmierć jest następstwem śmiertelnej i zniszczalnej natury ciała $\langle 1$ Kor $15,44-54\rangle$; ale przede wszystkim rozważa $w$ niej stronę religijną, tj. stosunku do Boga i do zamia-rów Bożych. Bogactwo treści sprawia zaś, że w różnych kontekstach coraz to inne cechy wysunięte bywają na miejsce naczelne i definiują śmierć. I tak, w 2 Tm 1, 10 ,śmierć", thanatos oznacza nie tylko grzech, ale także cielesną śmierć oraz śmierć wieczną, czyli potępienie. Przeciwstawia się bowiem życiu i nieśmiertelności, które dzięki Chrystusowi zabłysnęły poprzez Ewangelię. Kiedy zaś w 2 Kor 7, 10 czytamy: ,Smutek, który jest z Boga, sprawia nawrócenie i zbawienie, 
a smutek tego świata sprawia śmierć", przeciwstawiona jest śmierć nawróceniu i zbawieniu, czyli oznacza grzech oraz śmierć wieczn ą. Ponieważ Stary Testament widział istotę religijną śmierci w oddaleniu od Boga, równieź św. Paweł wychowany na nim nazywa śmiercią s a m grzech: w Rz 7, 10; 7, 13; 7, 24, 8, 2 oraz Cf 2, 1-5. W najmocniejszym swym znaczeniu wreszcie śmierć jest to śmierć wieczna, czyli wiekuiste odrzucenie od Boga, tj. potepienie. Występuje ono w $\mathrm{Rz} 6,21 ; 6,23$. Jest to znaczenie Mdr, przedstawione w poprzednim ustępie, a podobne do tego, jakie śmierci nadawał Jezus, gdy mówił do Marty: „Kto wierzy we mnie, chociażby i umarł, żyć będzie" (J 11, 25). Ale wyrazowi ,śmierć", thanatos, nadaje św. Paweł również znaczenie przenośne, oznaczając nim śmi e r ć g r z e c ho wi, czyli życie dla Boga w Chrystusie; np. w Rz 6, 2 nn.

Uważny rzut oka na powyższy zestaw zastosowań wyrazu śmierć, thanatos, przez św. Pawła jest pouczający. Wskazuje naprzód jak bardzo bogatą treść ma Pawłowe całościowe pojęcie śmierci, skoro składają się na nią: 1) grzech — jako przyczyna; 2) śmierć cielesna i 3) śmierć wieczna czyli wiekuiste odrzucenie od Boga. Po wtóre co tego, by można było mówić o śmierci, nie jest konieczne, by wszystkie te trzy składniki były obecne; św. Pawłowi wystarcza do tego urzeczywistnienie jednego tylko składnika. Wreszcie ta różnorodność znaczeń dowodzi, że byłoby grubym błędem, gdybyśmy z wyrazem ,śmierć" w listach św. Pawla wiązali na-sze, czysto formalne $i$ ontologiczne znaczenie. Albowiem nawet wtedy, gdy św. Paweł pisze o śmierci cielesnej, nie rozumie jej czysto formalnie i w oderwaniu od towarzyszących aspektów religijnych: np. w cieIesnej śmierci Chrystusa widzi nie samą tylko śmierć, ale śmierć dla grzechu ( $\mathrm{Rz} 6,10)$, to znaczy na zadośćuczynienie za grzechy ludzkie.

$\mathrm{Z}$ powyższego przeglądu znaczeń wyrazu śmierć, thanatos - który nie jest wyczerpujący - widać, jak bardzo ścisły związek w myśli św. Pawła istnieje między grzechem a śmiercią. Przejmuje on mianowicie tradycyjne w Starym Testamencie twierdzenie, że grzech po.* woduje śmierć grzesznika tą drogą, żéśmierć jest ,zapłatą"za grzech.

Grzech bowiem jest w oczach św. Pawła drogą do śmierci, na śmierí, eis thanaton ( $\mathrm{Rz}$ 6, 16), w przeciwstawieniu do posluszeństwa, które prowadzi do, eis, usprawiedliwienia. Wyraźniej mówiąc, „śmierć jest końcem, telos, grzechu" (Rz 6, 21), podobnie jak celem i końcem telos świątobliwości jest życie wieczne ( $\mathrm{Rz} 6,22$ ). Ponieważ w tym samym kon-. tekście śmierć jest dwukrotnie przeciwstawiona życiu wiecznemu, św. Pawel z pewnościa myśli tu o śmierci wiecznej, a nie o prostej śmierci cie-lesnej. Tę samą myśl wypowiada jeszcze wyraźniej w Rz 6, 23: „zapłatą, opsõmia, za grzech jest śmierć, a łaską Boga życie wieczne”. Nie ulega 
najmniejszej wątpliwości, że śmierć — ze względu na przeciwstawienie do życia wiecznego — oznacza w tym ważkim twierdzeniu śmierć wiecz ną, czyli wiekuiste oddalenie i odrzucenie od Boga. Smierć cielesna nie jest wprost oznaczona, ale tylko założona. Nie ma również najmniejszej wątpliwości, że grzech, amartio, paraptõma, w całym 6 rozdz. jest grzechem osobistym. Jedno tylko znaczenie wyrazu opsõmia, „zapłata”, nie jest dostatecznie pewne. Niektórzy bowiem rozumieją przez opsõmia zapłatę, wynagrodzenie, inni natomiast — żołd żołnierski. Ale również żołd jest zapłatą za służbę wojskową, jaka się należy żołnierzowi. Jeśli więc zdefiniujemy szerzej pojęcie zapłaty, tzn. jeśli zrezygnujemy z wymagania równowartościowości między zapłatą a usługą, bez obawy o zniekształcenie myśli św. Pawła możemy przez opsõmion rozumieć n a le ż$\mathrm{n}$ ą $\mathrm{z}$ a płatę. Na koniec jest bezsporne, że śmierć jest tą zapłatą dla popełniającego grzech. Zatem ostatecznie myśl św. Pawła jest następująca: śmierć wi eczna, czyli potępien ie grzeszącego jest $\mathrm{zapłatą} \mathrm{należną} \mathrm{za} \mathrm{grzech.} \mathrm{Ta} \mathrm{zasada} \mathrm{odnosi} \mathrm{się} \mathrm{więc} \mathrm{wprost}$ i właściwie tylko do śmierci wiecznej; a do śmierci cielesnej tylko ubocznie, in obliquo, z tego względu, że przejście przez śmierć cielesną jest założone przez śmierć wieczną.

Na przyczynowy związek między grzechem a śmiercią wskazuje również obrazowe powiedzenie 1 Kor 15, 56: „Ościeniem, kentron, śmierci jest grzech". Znajduje się ono przy końcu dłuższego ustępu, w którym św. Paweł utwierdza i wyjaśnia wiarę w zmartwychwstanie cielesne na końcu świata. Przez nie — twierdzi — zostanie ostatecznie przezwyciężona śmierć (1 Kor 15, 51-58). Dlatego ,śmierć” — w tym rozdziale -oznacza śmierć cielesną jako następstwo grzechu; jest ona przy tym uosobiona i posiada rysy żywej osoby nieprzyjaznej grzesznikowi i sprawującej nad nim władzę. Dlatego kentron, które w znaczeniu właściwym jest ostrym bodźcem służącym do popędzania bydła, posiada znaczenie przenośne i oznacza narzędzie, poprzez które śmierć sprawuje swą dyktatorską władzę nad grzesznym człowiekiem. Grzech osobisty mianowicie powoduje nieuchronnie religijnie - nie naturalistycznie i nie czysto formalnie - pojętą śmierć grzesznika. Chociaż spośród jej składników tylko śmierć cielesna jako następstwo grzechu jest w 1 Kor 15 bezpośrednio oznaczona, zapewne również i śmierć wieczna duszy jest milcząco współoznaczona, jako że należy do Pawłowego pojęcia śmierci jako następstwa grzechu.

Starotestamentalna zasada ,grzech pociąga religijnie pojętą śmierć grzesznika" również u św. Pawła jest niezależna od wykładni $\mathrm{Rdz} 2-3$; wprost przeciwnie, służy za podstawę do interpretowania $\mathrm{Rdz} 2-3$; występuje zatem jako jeden $z$ podstawowych objawów ładu etyczno-religijnego ustanowionego przez Boga. 
Posługiwanie się nią nie jest wprawdzie widoczne w 1 Kor 15, 21-22, gdzie czytamy: ,przez człowieka 〈przyszła〉 śmierć... i ... w Adamie wszyscy umierają". Ale jest to nader lakoniczna wzmianka i w 1 Kor 15 brak podstaw do odpowiedzi na pytanie, jak św. Paweł rozumie przyczynowy wpływ Adama na naszą śmierć. Dlatego 1 Kor 15, $21-22$ musi być tłumaczone przez $\mathrm{Rz} 5,12-21$, gdzie św. Paweł szerzej przedstawia rodzaj tej przyczynowości.

Słynny w historii dogmatów Rz 5, 12-21 jest najważniejszą — ale nie jedyną - podstawą biblijną dla katolickiej nauki o powszechnym pierworodnym grzechu dziedzicznym i dlatego trudno znaleźć w Biblii drugie miejsce, o którym by teologowie, dogmatycy i bibliści, równie wiele rozprawiali ${ }^{13}$. Ale dotychczasowe rozprawy zajmowaly się przede wszystkim wpływem grzechu Adamowego na zaistnienie grzechu pierworodnego, natomiast naturą tegoż wpływu na naszą śmierć nie interesowano się zupełnie. Usprawiedliwieniem tego zaniedbania jest struk.. tura kontekstu, w którym wpływ Adamowego grzechu na naszą śmierć jest składnikiem czysto pomocniczym i pięciorzędnym: nie jest tezą objawioną, którą św. Paweł chce przekazać czytelnikom, ale wyłącznie argumentem, którym objawioną naukę podbudowuje wobec czytelników. Właściwym jego zamysłem jest bowiem przekonanie czytelników o tym, że wszyscy ludzie dostępują usprawiedliwienia darmo przez wiarę w Chrystusa. Aby ich o tym przekonać, wskazuje na powszechny wpływ zbawczy Chrystusowego posłuszeństwa: oto składnik drugorzędny. Aby z kolei ułatwić przyjęcie tego argumentu, odwołuje się do

13 Oto tekst w tłumaczeniu Biblii tysiąclecia: ,(12) Jak przez jednego człowieka grzech wszedł na świat, a przez grzech śmierć, i w ten sposób śmierć przeszła na wszystkich ludzi, ponieważ wszyscy zgrzeszyli... (13) Bo i przed Prawem grzech był na świecie, grzechu się jednak nie poczytuje, gdy nie ma Prawa. (14) A przecież śmierć rozpanoszyła się od Adama do Mojżesza nawet nad tymi, którzy nie zgrzeszyli przestępstwem na wzór Adama. On jest typem Tego, który miał przyjść. (15) Aie nie tak samo ma się rzecz z przestępstwem jak z darem łaski. Jeżeli bowiem przestępstwo jednego sprowadziło na wszystkich śmierć, to o ileż obficiej spłynęła na nich wszystkich łaska i dar Boży, laskawie udzielony przez jednego Człowieka, Jezusa Chrystusa. (16) I nie tak samo ma się rzecz z tym darem jak i ze skutkiem grzechu, spowodowanym przez jednego grzeszącego. Gdy bowiem jeden tylko grzech przynosi wyrok potępiający, to łaska przynosi usprawiedliwienie ze wszystkich grzechów. (17) Jeżeli bowiem przez przestępstwo jednego śmierć zakrólowała z powodı jego jednego, o ileż bardziej ci, którzy otrzymują obfitość łaski i daru sprawiedliwości, królować będą w życiu z powodu Jednego - Jezusa Chrystusa. (18) A zatem, jak przestępstwo jednego sprowadziło na wszystkich ludzi wyrok potępiający, tak czyn sprawiedliwy Jednego sprowadza na wszystkich ludzi usprawiedliwienie dające życie. (19) Albowiem jak przez nieposłuszeństwo jednego człowieka wszyscy stali się grzesznikami, tak przez posłuszeństwo Jednego wszyscy staną się sprawiedliwymi. (20) Natomiast Prawo weszło, niestety, po to, by przestępstwo jeszcze bardziej się wzmogło. Gdzie jednak wzmógł się grzech, tam jeszcze obficiej rozlała się łaska, (21) aby jak grzech zaznaczył swoje królowanie śmiercią, tak łaska przejawiła swe królowanie przez sprawiedliwość wiodącą do życia wiecznego przez Jczusa Chrystusa, Pana naszego." 
biblijnej nauki o naszej powszechnej grzeszności: usprawiedliwienie przez wiarę i wpływ zbawczy posłuszeństwa Chrystusowego jest tak samo rzeczywisty i powszechny jak nasza grzeszność. To jest składnikiem trzeciorzędnym kontekstu logicznego. Aby podbudować powszechność naszej grzeszności, powołuje się na powszechną śmiertelność: co stanowi składnik czwartorzędny. Uzasadnienie powszechnej śmiertelności przez grzech Adama jest więc składnikiem pięciorzędnym. Mocą dogmatycznej nauki o natchnieniu Pisma św. nieomylną nauką objawioną jest tylko to, co autor natchniony chce przekazać czytelnikom; wszystko zaś, co ten autor wprawdzie przytacza, ale nie podaje - ani wyraźnie ani równoważnie za naukę którą chce wpoić czytelnikom, nie jest nieomylną nauką Objawienia. Tymczasem św. Paweł nie mówi, że wpływ grzechu Adama na naszą śmierć jest nauką objawioną, którą on przekazuje a wierni mają obowiązek przyjąć; przedstawiona struktura logiczna wywodów jest zaś przeciwko temu. Wobec tego wniosek $\mathrm{z}$ powyższych analiz może być tylko jeden: Jeśli skądinąd - z Biblii lub Tradycji — nie wiadomo, że wpływ grzechu Adama na naszą śmierć jest nauką objawioną, logiczna struktura wywodów $\mathrm{Rz} 5,12-21$ nie daje wystarczających podstaw do tego, by go uznać za obowiązującą treść Objawienia.

Co więcej: z treści pojęć, jakimi Rz 5, 12-21 posługuje się mó-wiąc o wpływie grzechu Adama na naszą śmierć, ni e mo żn a w o góle wyciągnąć wniosku, że człowiek przed upadkiem miał obiecaną nieśmiertelność cielesną w tym formalnym znaczeniu, w jakim o śmierci i nieśmiertebności mówi tradycyjna teologia pozanaturalnego daru nieśmiertelności. Albowiem wywody św. Pawła nie dotyczą śmierci cielesnej formalnie i po prostu pojętej, ale śmierci jako następstwa grzechu osobistego, a nie pierworodnego. Nie ulega bowiem żadnej wątpliwości, że w Rz 5 mowa jest o śmierci w religijnym pojęciu Pawłowym, przedstawionym na początku tego ustępu, oraz o grzechu osobistym jako jej przyczynie. Dwukrotnie - w w. 12 i 14 - pisze, iż umierali ci, co zgrzeszyli, i używa czasu historycznego, aorystu émarton, czyli ponad wszelką wątpliwość uważa dokonany akt grzechu za powód śmierci. Po wtóre āmartano, grzeszę, i amartia, grzech - oznaczają w Piśmie św. zawsze akty grzechu. Tak samo parakoe, nieposłuszeństwo $(5,19)$, parabasis $(5,14)$, paraptõma $(5,15-16-17-18)$ przestępstwo są nazwami czynności. Takiego tłumaczenia domaga się dla $\mathrm{Rz} 5$ biblijne słownictwo i nie trzeba się bynajmniej obawiać, że przez nie grzech pierworodny zostanie zagubiony. Albowiem równoważne, formaliter implicitum, ale zupełnie pewne świadectwo jego istnienia, powszechności i powodzenia daje nam wiersz 19: ,,przez nieposłuszeństwo jednego człowieka wszyscy stali się grzesznikami, amartoloi katestathésan oi polloi". 
Jak kowalem jest nie tylko ten, kto aktualnie kuje żelazo, lecz kto posiada sprawność uzdalniającą go do kucia, tak samo grzesznikiem jest nie tylko ten, kto już zgrzeszył lub grzeszy, ale i ten, którego bytowanie ludzkie nie może być bez grzechu. Do takiego stanu sprowadził naturę ludzką grzech osobisty Adama, a stan ten jest brakiem darów łaski uświęcającej, uzdalniających do skutecznej walki z pokusami; jest zatem stanem grzechu pierworodnego.

Ponieważ w $R z 5$ mowa o śmierci jako następstwie grzechu osobistego, wyraz ten wyraźnie i bezpośrednio oznacza śmierć cielesną, ale równocześnie współoznacza wieczną śmierć duszy, która jest zapłatą należną za grzech $(\mathrm{Rz} 6,23)$. Nieodzownie koniecznym warunkiem logicznej poprawności i skuteczności jakiegokolwiek wnioskowania i dowodzenia jest, by wszystkie wyrazy zachowywały tę samą treść czyli oznaczały te same pojęcia w całym jego przebiegu. Zatem Pawłowe znaczenie wyrazu śmierć w Rz 5 dozwala jedynie na wniosek: przed upadkiem Adama nie istniała śmierć jako zapłata za grzech, czyli śmierć cielesna związana $z$ śmiercią wieczną. Natomiast można nie wywnioskowac ani o istnieniu ani o nieistnieniu śmierci cielesnej, rozumianej formalnie i bez powiązania z śmiercią wieczną, czyli z Rz 5 nie można w ogóle niczego wnosić o cielesnej niemiertelności, formalnie pojętej przed upadkiem. Każde zaś wnioskowanie o niej dopuszcza się co najmniej dwu błędów logicznych: wieloznaczności słów, fallacia aequivocationis, oraz pojęciowego przeskoku, quaternio terminorum.

Po trzecie: rodzaj argumentu, zastosowanego przez św. Pawła w Rz 5, 12 nn, wyklucza możliwość wnioskowania o cielesnej nieśmiertelność człowieka przed upadki e m. Jeśli mianowicie człowiek przed upadkiem miał warunkową nieśmiertelność cielesną z obietnicy Bożej, to stąd w sposób konieczny wynika, że grzech osobisty Adama jest właściwą przyczyną utraty tejże nieśmiertelności przez wszystkich ludzi, czyli ich śmierci. Inaczej mówiąc, jego grzech — w takim założeniu — ponosi bezpośrednią winę za naszą śmierć. Jak tymczasem argumentuje św. Paweł? Wprawdzie aż czterokrotnie - w wierszach 15, 16, 17, 18 - wiąże naszą śmierć wprost z grzechem osobistym Adama, ale nie jest to jego cała myśl, lecz skrót myślowy. Albowiem pełny swój pogląd na sposób powiązania naszej śmierci z grzechem Adama przedstawia w tym samym ustępie również czterokrotnie: w wierszach 12, 13, 18 i 19, 20 i 21. Najmocniej i najwyraźniej wypowiada się w w. 12: „Przez jednego człowieka grzech wszedł na świat, a przez grzech śmierć; i w ten sposób śmierć przeszła na wszystkich ludzi, bo wszyscy zgrzeszyli”. Z wiązek między naszą śmiercią, a grzechem Adama jest zatem pośred-ni. Wprost i bezpośrednio, czyli właściwie sprawił to, że „wszyscy stali 
się grzesznikami” $(5,19)$, którzy nie mogą nie grzeszyć aktualnie. A dopiero aktualne nasze osobiste grzechy powodują naszą śmierć, która jest zapłatą za nie $(\mathrm{Rz} 6,23)$. Z tego zaś jasno widać, że argumentacja św. Pawła bynajmniej nie zakłada cielesnej nieśmiertelności człowieka przed upadkiem; zatem $\mathrm{z}$ argumentacji $\mathrm{Rz} 5$ nie można nic o tej nieśmiertelności wnioskować.

Wyniki rozważań tego ustępu podsumuje następujące twierdzenie, naukowo omylnie pewne a epistemologicznie prawdopodobne: Listy św. Pawła nie dają wystarczającej podstawy do tego, by uznać nieśmiertelność człowieka przed upadkiem za naukę istotnie objawioną.

\section{WNIOSKI I NASTĘPSTWA}

Wszystkie rozważania na temat cielesnej nieśmiertelności przed upadkiem w Piśmie św. uprawniają do następującego naukowo omylnie pewnego - a epistemologicznie prawdopodobnego - wniosku: Ani nawiązania do Rdz $2-3$, ani zasada biblijna, że grzech sprowadza śmierć grzeszącego, nie dają wystarczającej podstawy do twierdzenia, że ta nieśmiertelność jest nauką Pisma św. istotnie objawioną i nieomylną.

Tym samym traci podstawę biblijną stanowisko Pawłowego Credo Narodu Bożego, że jej odrzucenie jest niebezpieczne dla wiary.

Wszystkie rozważania wykazały tylko to, że nie ma podstaw do uznania tej nieśmiertelności za istotnie objawioną; nie udowodniły natomiast wprost, że nie jest objawiona. Pozostaje zatem otwarta możliwość, że Magisterium - kierowane przez Ducha Sw. - znajdzie w Objawieniu jakieś inne podstawy wyjaśnienia, ad explicandam fidem, że jest ona istotnie objawiona.

Dopóki Urząd nauczycielski Kościoła nie dostarczy takiego wyjaśnienia Objawienia, mogą teologowie odstąpić od nieśmiertelności cielesnej w teologicznej interpretacji stanu sprawiedliwości pierwotnej, pod warunkiem, że głos rozstrzygający pozostawią Kościołowi, a swą teorię będą uważać za epistemologicznie prawdopodobną i tymczasową.

Za rezygnacją z cielesnej nieśmiertelności pójdzie porzucenie pozo-stałych darów pozaprzyrodzonych stanu sprawiedliwości, który w ten sposób przestanie być stanem i miejscem doczesnej doskonałości i szczęśliwości. Raj - w takim ujęciu - będzie udziałem ludzkości dopiero po końcu historii ludzkości i świata; po powtórnym przyjściu Chrystusa. Również i obecna epoka historii naszego zbawienia - ta od upadku pierworodnego po sąd ostateczny - będzie wyraźniej doskonalsza od pierwotnej. Obraz stanu sprawiedliwości pierwotnej będzie zatem bardziej zgodny z ewolucyjnym obrazem świata. 


\section{HIPOTETYCZNY ZARYS CAEOSCI DZIEJOW ZBAWIENIA}

Po rezygnacji z warunkowej nieśmiertelności i z pozostałych darów pozanaturalnych, a przy zachowaniu wszystkich treści dogmatycznych trydenckiego dekretu o grzechu pierworodnym przedstawiałby się on następująco:

Od pierwszej chwili swego istnienia na ziemi, na której pojawił sią naprzód jako homo erectus, człowiek żył w stanie łaski uświęcającej; nie tylko nie był grzesznikiem, nie tylko był bez grzechu, ale był wewnętrznie wyposażony w tę sprawiedliwość i świętość, która zapewniała wiekuiste szczęście duszy u Boga. Albowiem jest nauką Rdz, czyli zarówno dokumentu jahwistycznego jak Kodeksu Kapłańskiego, że człowiek stworzony przez Boga był dobry - jako człowiek; czyli etycznie dobry i bez grzechu. A Mdr 2, 23 poszła o krok dalej twierdząc, że Bóg stworzyi człowieka do szczęśliwej nieśmiertelności w bliskości Boga, która będzie udziałem duszy sprawiedliwego po cielesnej śmierci. Wynika stąd, że dając człowiekowi istnienie, Bóg równocześnie wyposażył go w sprawiedliwość nieodzowną do osiągnięcia tego szczęścia. Z Nowego Testamentu wiadomo, że jest to nadprzyrodzona sprawiedliwość przybranych dzieci Bożych.

Udzielenie człowiekowi darów tej nadprzyrodzonej sprawiedliwości i świętości stanowiło część stwórczego planu Bożego, który związał jej posiadanie z naturą ludzką i dlatego każdy człowiek - aż do pierworodnego upadku - rodził się bez grzechu i w stanie łaski.

Posiadanie darów sprawiedliwości i świętości zapewniało człowiekowi - jak świadczy Mdr 1 i 2 - przezwyciężenie śmierci cielesnej: albowiem nie tylko cały człowiek, złożony z duszy i ciała, ale tym bardziej sama dusza oddzielona od ciała, nie była zdolna zdobyć własnymi siłami ani tyle ani takiego szczęścia, jakie dawał Bóg w nagrodę za sprawiedliwość, duszom sprawiedliwych po cielesnej śmierci. Dopuszczając je mianowicie do udziału w swym własnym boskim szczęściu, dawał im tym samym życie nieporównanie pełniejsze i doskonalsze od tego, jakie wiodły w zjednoczeniu z ciałem.

Ponieważ jednak łaska nie przekreśla natury, nadprzyrodzone ubogacenie człowieka przed upadkiem ograniczało się do wewnętrznej, religijno-etycznej dziedziny: nie zmieniając jego naturalnych struktur cielesnych, zmysłowych i umysłowych oraz nie usuwając ich pierwotności i niedoskonałości. Jak jednostka ludzka rozwija się od dzieciństwa do wieku dojrzałego, podobnie homo erectus był pod względem naturalnych struktur rasą niedoskonalszą od późniejszego człowieka, homo sapiens, a najpierwsi przedstawiciele rasy homo erectus byli mniej rozwinięci, niż ich potomkowie. Jest to zgodne zarówno z ewolucyjnym obra- 
zem świata, jak i z tezą św. Tomasza, że niedoskonałość jest czasowo wcześniejsza od doskonałości w zakresie tego samego bytu (1, q 82, a 3, ad 2).

Dla prehistorii nie ulega wątpliwości, że dzisiejszy homo sapiens wyraźnie przerasta inteligencją nie tylko człowieka neandertalskiego, ale jeszcze bardziej wszystkich przedstawicieli rasy homo erectus. A od poziomu inteligencji uzależnione jest życie etyczne w ten sposób, że im wyraźniejsze jest rozumowe poznanie dobra lub zła, tym czyn ludzki jest bardziej wolny i odpowiedzialny; tym bardziej jest czyn moralnie dobry lub zły. Wobec tego ani neandertalczyk ani żaden homo erectus nie byli odpowiedzialni za swe czyny w takim samym stopniu jak człowiek współczesny. Jeśli grzeszyli, ich grzech nie dorastał nigdy do teologicznych wymiarów grzechu śmiertelnego, czyli nie miał znamion odwrócenia się od Boga i miłości własnej posuniętej aż do pogardy Boga. Grzeszyli więc lekko i nie tracili przez grzech tej sprawiedliwości i świętości, w której się urodzili. Faktycznie zaś istnienie grzechów lekkich w całym okresie sprawiedliwości pierwotnej jest następstwem braku darów pozanaturalnych. Z drugiej strony zaistnienie grzechu śmiertelnego, który pozbawia człowieka stanu łaski, było dopiero możliwe na intelektualnym poziomie „człowieka mądrego”; czyli stan sprawiedliwości pierwotnej trwał długie tysiące lat. A hipoteza tych, którzy utrzymują, że człowiek zbuntował się przeciw Bogu zaraz w swym pierwszym akcie ludzkim, jest nie do pogodzenia z nauką Pisma św., że Bóg stworzył człowieka dobrym.

Im dłuższy jest okres czasu, tym bardziej prawdopodobne staje się urzeczywistnienie tego, co jest możliwe. A grzech powszechnej apostazji od Boga był rzeczywiście możliwy na poziomie rasy homo sapiens. Otóż w jakimś okresie dziejów „człowieka mądrego” grzech śmiertelny tak się rozpowszechnił i tak się nasilił, że doszło do powszechnej apostazji od Boga. Jeśli były jakieś jednostki wierne Bogu, były one tak wyjątkowo nieliczne, że bez przesady twierdzić można, że ludzkość odwróciła się od Boga i wzgardziła nim. Tradycja o tym powszechnym odstępstwie zachowała się $\mathrm{w}$ biblijnym przekazie o potopie, w którym występuje pięć składników: powszechna apostazja, wierność rodziny Noego, gniew Boga, zagłada odstępców, przymierze Boga z Noem. Nie ma natomiast mowy o niewidzialnych skutkach powszechnej apostazji i o jej wpływie na dalszą historię ludzkiego zbawienia, albowiem w Pięcioksięgu brakowało jeszcze pojęć i słów do ich wyrażenia. Uzupełniając ten brak powiemy - w świetle całości objawienia Starego i Nowego Testamentu:

Upadkiem pierworodnym, peccatum originale originans, który zakończył pierwotny okres historii zbawienia i rozpoczął jej okres obecny, 
był właśnie grzech powszechnej apostazji od Boga, którego w swej przeszłości dopuścił się homo sapiens. Ta bowiem powszechna apostazja pociągnęła za sobą powszechność grzechu pierworodnego w nas, peccatum originale originatum, czyli zawiniony brak łaski u wszystkich odtąd ludzi: skoro mianowicie ludzkość wzgardziła Bogiem i jego łaską, Bóg postanowił nie wiązać ná przyszłość posiadania laski z otrzymaniem natury ludzkiej przez zrodzenie naturalne. Dlatego wszyscy ludzie rodzą się obecnie grzesznikami ( $\mathrm{Rz} 5,19)$.

Przymierze z Noem oznacza, że Bóg nie zaprzestał miłować człowieka po upadku. Przeciwnie, zaczął mu dawać dowody jeszcze większej miłości niż przed upadkiem. Albowiem zerwanie automatycznego otrzymywania łaski razem z naturą ludzką przy zrodzeniu było tylko częścią nowego, pod każdym względem doskonalszego porządku zbawienia, który Bóg postanowił urzeczywistnić po pierworodnym upadku. W tym, obecnym porządku jest naprzód większe zbliżenie się Boga do człowieka, niż było przed upadkiem; albowiem Bóg jest obecnie nie tylko przyjacielem i najlepszym Ojcem dla człowieka, ale, przez Wcielenie, jest wprost człowiekiem. Obecny porządek jest z kolei bogatszy w dobra łaski zbawiennej, a te dzięki doskonałości zasług Boga-człowieka ( $\mathrm{Rz}$ 5, 15-17). Obecnie jest również pełniejsze niż przed upadkiem osiągnięcie celu religii, to jest wybawienia; albowiem dzięki zasługom Chrystusowym udziałem człowieka jest obecnie podwójne - i całkowite - przezwyciężenie śmierci: przez niebieską szczęśliwość duszy oraz przez zmartwychwstanie ciał. Wreszcie godność i wolność osoby ludzkiej bardziej zaznacza się w obecnym porządku zbawienia, w którym łaska nie jest automatycznie związana z posiadaniem natury ludzkiej.

Ale z wolnością woli wiąże się możliwość wszelakiego rodzaju grzechów; zatem możliwość ponownej i powszechnej apostazji ludzkości. Po dostatecznie długim okresie czasu prawdopodobieństwo takiej apostazji zamieni się w pewność, bo powszechne odwrócenie się ludzkości od Boga stanie się po raz drugi faktem. To drugie odstępstwo poprzedzi - według 2 Tes 2, 3 - uroczyste przyjście Chrystusa na sąd i zakończy całą historię zbawienia.

Wielkość i boskość swej miłości do człowieka po upadku objawił Bóg w ten sposób, że zaofiarował ludzkości niepomiernie więcej, niż przed upadkiem. Posunął się do tego, że dał jej to, co miał najdroższego, czyli siebie samego - stając się człowiekiem. Po drugiej apostazji nie bedzie więc mógł jej ofiarować niczego większego. Dlatego po niej nie będzie trzeciego, jeszcze doskonalszego okresu historii zbawienia; a wielkość i wspaniałomyślność swej miłości objawi Bóg w ten sposób, że stawanie się zbawienia ustąpi miejsca zbawieniu dokonanemu. 
Powszechna apostazja przed „końcem” świata będzie równoznaczna z widzialnym niepowodzeniem drugiego i to doskonalszego porządku zbawienia. Dlatego uroczysty i powszechny sąd ostateczny będzie konieczny dla spełnienia celu stworzenia świata, bo dopiero na nim objawi się wszystkim ludziom — również złym odstępcom - w całej oczywistości wielkość Boga. 